\title{
Milicianos, barbeiros e traficantes numa irmandade católica de africanos minas e jejes (Bahia, 1770-1830) ${ }^{1}$
}

\author{
Luis Nicolau Parés[1]
}

\begin{abstract}
Resumo
Este artigo apresenta o perfil de alguns africanos que pertenceram à irmandade do Bom Jesus das Necessidades e Redenção, ereta na capela do Corpo Santo de Salvador, entre o último quartel do século XVIII e o início do XIX. A partir de uma série de esboços biográficos, o texto indaga quais laços étnicos, de parentesco, afetivos, profissionais e comerciais esses africanos mantinham entre si, e o que essa sociabilidade nos diz a respeito do papel da irmandade como instituição.
\end{abstract}

Palavras-chave: libertos africanos; Bahia; irmandade católica; jeje; tráfico de escravos.

Los milicianos, barberos y traficantes en una hermandad católica de africanos minas y jejes (Bahia, 1770-1830)

Resumen

En este artículo se presenta el perfil de algunos africanos que pertenecían a la hermandad de Bon Jesús de las Necesidades y la Redención, que se erigió en la capilla del Santísimo Cuerpo de Salvador, entre el último cuarto del siglo XVIII y principios del XIX. Con el análisis de una serie de bosquejos biográficos, el texto investiga cuáles son los lazos étnicos, de parentesco, afectivos, profesionales y comerciales entre esos africanos, y lo que esa sociabilidad nos informa acerca del papel de la hermandad como institución. Palabras clave: libertos africanos; Bahia; hermandad católica; jeje; comercio de esclavos.

Militiamen, barbers and slave-traders: Mina and Jeje Africans in a catholic brotherhood (Bahia, 1770-1830)

\begin{abstract}
This article presents the profile of a group of Africans who belonged to the brotherhood Bom Jesus das Necessidades e Redenção, housed in the chapel of Corpo Santo, in Salvador, between the last quarter of the 18th century and the early 19th century. On the basis of a series of biographical sketches, the paper investigates the ethnic, familial, affective, professional and commercial bonds Africans maintained amongst themselves, and discusses what this sociability reveals about the role of the brotherhood as an institution.

Keywords: freed Africans; Bahia; catholic brotherhood; Jeje; slave trade.
\end{abstract}

\section{Militants, barbiers et trafiquants dans une fraternité catholique d'Africains 'minas' et 'jejes' (Bahia, 1770-1830)}

\section{Résumé}

Cet article présente le profil de certains africains de la fraternité Bom Jesus das Necessidades e Redenção, créée dans la chapelle Corpo Santo, à Salvador (BA), Brésil, dans la période comprise entre la fin du 18ème siècle et le début du 19ème. Sur la base de données biographiques, on demande quels liens ethniques, de parenté, affectifs, professionnels et commerciaux ces africains avaient maintenu entre eux, et ce que ces relations reflètent du rôle de la fraternité en tant qu'institution.

Mots clés: libérés africains; Bahia; fraternité catholique; jeje; trafic des esclaves. 
A historiografia sobre as irmandades católicas de homens negros tem reconhecido a importância desses espaços de sociabilidade africana no Atlântico lusófono, com destaque para a América portuguesa. Por meio da análise dos compromissos e, mais raramente, dos livros de atas e de entrada das próprias irmandades, existe hoje um conhecimento pormenorizado da distribuição, da história, da organização social e da administração dessas instituições. ${ }^{2}$ Porém, essa bibliografia dificilmente permite enxergar quem eram os indivíduos que compunham essas confrarias. Este texto apresenta o perfil de alguns dos africanos que pertenceram à Irmandade do Bom Jesus das Necessidades e Redenção (IBJNR), ereta na capela do Corpo Santo de Salvador, entre o último quartel do século XVIII e o início do XIX. A partir de uma série de esboços biográficos, o texto indaga quais laços étnicos, de parentesco, afetivos, profissionais e comerciais esses africanos mantinham entre si e o que essa sociabilidade nos diz a respeito do papel da irmandade como instituição.

Antes disso, porém, faz-se necessário tecer algumas considerações relativas à constituição da agremiação. O compromisso de 1913, uma versão revista do original de 1775, informa que a IBJNR foi ereta "devoção" "por homens pretos africanos (gegês)" no ano de 1752 e elevada à categoria de irmandade de compromisso em 30 de maio de $1775 .{ }^{3} \mathrm{~A}$ data de 1752 aparece registrada pela primeira vez apenas no compromisso de 1913 e, portanto, deve ser tomada com cautela. ${ }^{4}$ No entanto, a existência de uma "devoção" prévia à instituição da irmandade e o seu traslado para a capela do Corpo Santo em 1774 são informações corroboradas por documentos da época.

Em 28 de agosto de 1774, os "devotos" do Senhor Bom Jesus das Necessidades e Redenção, "pretos geges", solicitavam aos administradores da capela e aos membros da irmandade de São Pedro Gonçalves a graça de colocar a imagem de sua devoção "no altar do glorioso São Caetano", acrescentando que pretendiam "erigir de novo sua irmandade; tendo já para isso alcançado as licenças necessárias [grifo do autor]." A expressão "de novo" sugere que houve uma tentativa anterior, talvez malsucedida, e fica claro que, até então, a imagem da devoção não estava na capela do Corpo Santo. Os suplicantes assinaram

\footnotetext{
${ }^{2}$ A literatura sobre irmandades é extensa. Para o Brasil, por exemplo: Julita Scarano, Devoção e escravidão: a irmandade de Nossa Senhora do Rosário dos pretos no Distrito Diamantino no século XVIII, São Paulo, Editora Nacional, 1978; Caio Boschi, Os leigos e o poder: irmandades leigas e política colonizadora em Minas Gerais, São Paulo, Ática, 1986; Antonia Quintão, Lá vem o meu parente: as irmandades de pretos e pardos no Rio de Janeiro e em Pernambuco no século XVIII, São Paulo, Ana Blume; Fapesp, 2002; João José Reis, "Identidade e diversidade étnicas nas irmandades negras no tempo da escravidão", Tempo, vol. 2, n. 3, Niterói, 1996, p. 7-33; Mariza de Carvalho Soares, Devotos da cor, Rio de Janeiro, Civilização Brasileira, 2000; Lucilene Reginaldo, Os Rosários dos Angolas: irmandades de africanos e crioulos na Bahia setecentista, São Paulo, Alameda; Fapesb, 2011.

${ }^{3}$ Compromisso da Irmandade do Senhor Bom Jesus das Necessidades e Redempção [aprovado] aos 26 de dezembro de 1913, Bahia, Baptista Costa, 1914, p. 5. Ver também "A igreja do Corpo Santo", A Tarde, 6 de janeiro de 1934, apud Mons. Manoel de Aquino Barbosa, Retalhos de um Arquivo, Salvador, 1972, p. 92-95.

${ }^{4} \mathrm{O}$ compromisso de 1913 contém outro equívoco ao informar que a devoção foi ereta na igreja de Conceição da Praia, em 1752, pois, entre 1736 e 1765, essa igreja foi demolida e reconstruída, servindo a capela do Corpo Santo como igreja matriz da paróquia: João da Silva Campos, Procissões tradicionais da Bahia, 2. ed. rev. Salvador, Conselho Estadual de Cultura, 2001 [1941], p. 265. Esse equívoco foi corrigido em publicações posteriores: Mons. Manoel de Aquino Barbosa, Efemérides da Freguezia de Nossa Senhora da Conceição da Praia, vol. 1, Salvador, Coleção Conceição da Praia, 1970, p. 43.
} 
um termo que deixa entrever as tensões hierárquicas latentes. Além de outras obrigações, como contribuir com as despesas da igreja, os africanos reconheciam a irmandade de São Pedro Gonçalves como "senhorios e administradores desta igreja a quem devem guardar toda a obediência e respeito", sob pena de serem expulsos "sem que se possam valer de qualquer direito ou posição".

A capela de São Frei Pedro Gonçalves, vulgarmente denominada do Corpo Santo (perto do atual elevador Lacerda, numa das esquinas da praça Cairu), era capela antiga de marinheiros, dedicada a São Telmo. ${ }^{6}$ Conta a lenda que o capitão espanhol Pedro Gonçalves teria iniciado suas obras em pagamento de uma promessa feita ao santo homônimo por tê-lo salvo de uma tempestade na Baía de Todos-os-Santos. A construção teria começado em 1694 e o viajante francês Amédée Frézier, em 1714, mencionava a capela do "Cuerpo Sto para as pessoas pobres e a Conceçaon para os marujos". Na década de 1730, houve uma tentativa frustrada de fundar, em volta dela, um hospital marítimo. Entre 1738 e 1765, período em que a capela da Conceição da Praia foi demolida para construir uma nova igreja, a do Corpo Santo funcionou como matriz da freguesia. A capela passou por sucessivas reformas e, na atualidade, quase nada se preserva da edificação original. ${ }^{7}$ Cabe notar que ela foi erguida de costas para o porto, numa tentativa de reduzir a maresia dentro do templo, pois até a década de 1820, antes do aterramento daquela área, ela ficava defronte ao cais, na primeira linha do mar (Figura 1).

Os historiadores que comentaram a IBJNR têm destacado a predominância étnica jeje entre os membros dessa congregação. Essa ideia foi inferida por Silva Campos e Pierre Verger da informação contida no compromisso de 1913 e depois reproduzida por vários outros autores. ${ }^{8}$ No termo de 1774 , anteriormente

\footnotetext{
${ }^{5}$ Papéis avulsos, Biblioteca da Igreja da Conceição da Praia (BICP), 1774

‘Sobre São Telmo: João da Silva Campos, "Tradições Bahianas", Revista do Instituto Geográfico e Histórico da Bahia (RIGHB), n. 56, 1930, p. 488; João da Silva Campos, Procissões tradicionais da Bahia, 2. ed. rev. Salvador, Conselho Estadual de Cultura, 2001 [1941], p. 365-69.

${ }^{7}$ Francisco Vicente Vianna, Memória sobre o Estado da Bahia, Salvador, Tipografia do Diário da Bahia, 1893, p. 334-35. Amédée François Frézier, Relation du Voyage de la Mer au sud des Côtes du Chill, du Perou et du Brésil, faites pendant les années 1712, 1713 et 1714, Amsterdam, Chez Pierre Humbert, 1717, t. 2, p. 536. Sobre o hospital marítimo: Arquivo Histórico Ultramarino (AHU), Conselho Ultramarino (CU), caixa 53, doc. 4.616, ant. 1.735; caixa 56, doc. 4.861, 1.736. Ver também Luiz Monteiro da Costa, "O Hospital Marítimo e a Confraria do Corpo Santo", RIGHB, n. 86, 1976-77 [1953], p. 27-40. Sobre a demolição da igreja da Conceição da Praia: O Noticiador Católico, ano V. n. 205, 1852, p. 143; Geraldo Sodré Martins, Nossa Senhora da Conceição da igreja da Praia, 1765: construção ou ampliação, Salvador, Fundação Cultural do Estado da Bahia, 1985, p. 17-18. Para o histórico arquitetônico da igreja, hoje tombada pelo Instituto do Patrimônio Histórico e Artístico Nacional (IPHAN): Paulo Ormindo de Azevedo (org.), Inventário de proteção do acervo cultural da Bahia, vol. 1, Monumentos do município de Salvador, Bahia, Salvador, Secretaria de Cultura e Turismo, 1975, p. 49-50.

${ }^{3}$ João da Silva Campos, op cit., p. 265-266; Pierre Verger, Fluxo e refluxo do tráfico de escravos entre o Golfo do Benin e a Bahia de todos os Santos, São Paulo, Corrupio, 1987 [1968], p. 525; Anthony John R. Russell-Wood, "Aspectos da vida social das irmandades leigas da Bahia no século XVIII", In: O bicentenário de um monumento bahiano, vol. 2, Salvador, Coleção Conceição da Praia, 1971, p. 151; Patricia Muvley, The black lay brotherhoods on colonial Brazil, Tese de doutorado, Columbia University, New York, 1976, p. 292; Kátia Mattoso, Bahia: a cidade do Salvador e seu mercado no século XIX, São Paulo, Hucitec; Salvador, Secretaria Municipal de Educação e Cultura, 1978, p. 21O; Kátia Mattoso, Bahia: século XIX - uma província no Império, Rio de Janeiro, Nova Fronteira, 1992, p. 401, onde se afirma que essa irmandade era "composta unicamente por jejes"; João José Reis, "Identidade e diversidade étnicas nas irmandades negras no tempo da escravidão", Tempo, vol. 2, n. 3, Niterói, 1996, p. 13; João José Reis, A morte é uma festa, São Paulo, Companhia das Letras, 1991, p. 55; Maria Inês Cortes de Oliveira, 0 liberto: o seu mundo e os outros (Salvador, 1790-1890), Salvador, Corrupio, 1988, p. 81. Ver ainda, Donald Pierson, Brancos e prêtos na Bahia: estudo de contacto racial, São Paulo, Nacional, 1971 [1942], p. 142.
} 


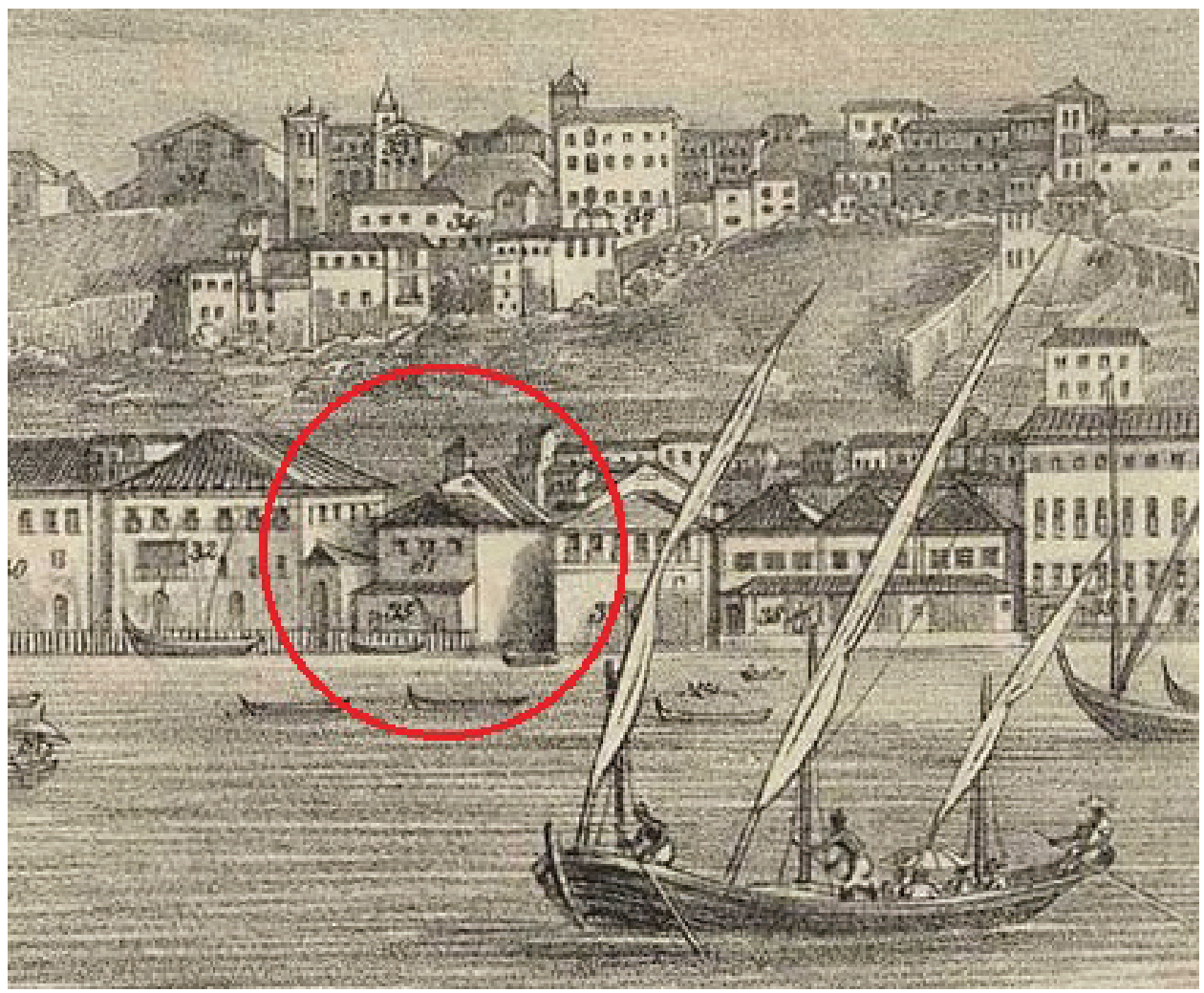

Figura 1. A igreja do Corpo Santo (no circulo vermelho). Fonte: A View of the City of Bahia in the Brazil, South America (detalhe). Drawn on Stone by G. Scharf, from a Sketch by Edmund Patten, taken on the Water at a Distance of half a Mile/Published by Edmund Patten in June 18th 1826/Printed by C. Hullmandel.

mencionado, os irmãos são, efetivamente, referidos como "pretos gêges", mas o capítulo 12 do compromisso original, redigido no ano seguinte, estipulava que "serão admitidos para irmãos, e irmãs os pretos nacionais da Costa da Mina, ou Loanda, excluindo da sua congregação os crioulos desta cidade, ou de outra qualquer parte" ${ }^{9}$

Ou seja, embora a irmandade pudesse estar dominada pelos jejes, a participação de africanos de outras etnias estava contemplada. Também brancos e pardos poderiam ingressar. O compromisso enfatizava apenas a exclusão dos crioulos, o que suscitou a objeção do promotor Antonio de Brito d'Assumpção. Porém, como arguiu o provedor de Resíduos e Capelas, Joaquim José Coelho da Fonseca, a medida não era novidade e almejava evitar os conflitos

\footnotetext{
9Do compromisso, se preservam duas versões: uma manuscrita, no Arquivo da Torre do Tombo (ATT), em Lisboa, e outra impressa, no Arquivo da Cúria Metropolitana de Salvador: 1.- ATT, Lisboa, Chancelaria da Ordem de Cristo, D. Maria I; Comuns 432; Livro 5; f. 51-60: "Compromisso do Bom Jesus das Necessidades Redempção, da cidade da Bahia”, Provisão de confirmação de compromisso: 28-08-1778; aprovado pelo Provedor de Resíduos e Capelas da mesma cidade, Deputado Procurador Geral das Ordens; escrito neste livro em 15 capítulos. Agradeço a Lucilene Reginaldo por ter providenciado cópia desse documento. 2.- Arquivo da Cúria Metropolitana de Salvador (ACMS), Est. 1; Cx. 32; Cx. Arq. 162-As1; doc. 38: "Bom Jesus das Necessidades e Redempção", Lisboa, Oficina de Antonio Rodrigues Galhardo, Impressor da Real Meza Censoria, 1778.
} 
e as controvérsias que se davam entre os pretos nascidos no país e aqueles de ultramar. ${ }^{10} \mathrm{O}$ compromisso foi despachado em 4 de outubro de $1775 \mathrm{e}$, finalmente, aprovado pelo Tribunal da Mesa da Consciência e Ordem, em Lisboa, em 22 de agosto de 1778, e por provisão real de 12 de setembro seguinte.

Baseado em informação contida num "antigo livro de resoluções da associação", Silva Campos descreve uma intricada sequência de conflitos étnico-raciais entre jejes, crioulos, mestiços e brancos no seio da confraria. ${ }^{11}$ Infelizmente, não consegui achar esse livro e, portanto, não foi possível estabelecer quando esses grupos entraram na irmandade ou a cronologia dos conflitos que se estenderam do século XVIII ao século XX. Na tentativa de melhor entender a composição étnica da irmandade, recorri à análise de testamentos, inventários e registros de óbito que mencionassem a IBJNR, levantando uma lista de 96 irmãos, falecidos no período de 1805 a $1855 .{ }^{12}$ Cabe notar que, para o período de 1780 a 1805, não encontrei ainda evidência do funcionamento da irmandade, um "buraco" documental que precisa de futuras pesquisas para sanar o problema. Contudo, alguns dos 96 irmãos identificados contavam entre os fundadores da agremiação nos anos 1770 .

\section{Embora a irmandade pudesse estar dominada pelos jejes, a participação de africanos de outras etnias estava contemplada. Também brancos e pardos poderiam ingressar}

A amostra disponível confirma, para o período em questão, a presença quase exclusiva de africanos na IBJNR. Na lista consta apenas um brasileiro, nascido em Camamu, também afiliado à irmandade de Nossa Senhora do Terço, na mesma igreja do Corpo Santo, que era de homens pardos. ${ }^{13}$ Fora esse caso, 24\% dos irmãos são identificados com categorias genéricas como Costa da África (13), Costa da Guiné (3), Gentio da Guiné (2), africano (3), ou não apresenta informação (2), sem que se possa afirmar qualquer coisa sobre sua origem étnica. Os $75 \%$ restantes se dividem numa maioria da África ocidental (68\% do total) e uma minoria da África centro-ocidental (7\%), incluindo

\footnotetext{
10Para uma análise das controvérsias entre africanos e crioulos nessa e em outras irmandades: João José Reis, "Identidade e diversidade étnicas nas irmandades negras no tempo da escravidão", Tempo, vol. 2, n. 3, Niterói, 1996, p. 15-17; Luis Nicolau Parés, "O processo de crioulização no Recôncavo baiano (1750-1800)", AfroÁsia, n. 33, 2005, p. 97-103.

"João da Silva Campos, Procissões tradicionais da Bahia, 2. ed. rev. Salvador, Conselho Estadual de Cultura, 2001 [1941], p. 265-266.

${ }^{12} \mathrm{~A}$ partir da década de 1830, a afiliação de libertos africanos às irmandades entrou em declínio: Maria Inês Cortes de Oliveira, O liberto: o seu mundo e os outros (Salvador, 1790-1890), Salvador, Corrupio, 1988, p. 8384; João José Reis, A morte é uma festa, São Paulo, Companhia das Letras, 1991, p. 151-152. No caso da IBJNR, há evidência de franca decadência depois de 1855, ano da epidemia do cólera, quando a procissão anual deixou de ser celebrada.

${ }^{13}$ Arquivo Público do Estado da Bahia (APEB), Judiciário, Livro de Testamentos n. 4, "Testamento de Francisco Xavier de Jesus", 1814, f. 46ss. Ele seria o senhor de Luis Xavier de Jesus, um jeje com participação ativa no tráfico de escravos.
} 
4 angolas, 1 benguela e 2 da Costa de Leste. A alusão no compromisso de 1775 à presença dos luandas, ou bem refletia uma realidade do século XVIII que mudou no século XIX, ou deve ser interpretada como um formalismo retórico para minimizar, aos olhos das autoridades eclesiásticas, qualquer tom partidário. Contudo, a potencial inclusão dos bantos pode esconder razões mais complexas, pois vários dos mesários minas e jejes da IBJNR viajavam com certa frequência a Luanda e Benguela.

Entre os originários da África ocidental, constam 36 irmãos (37\% do total) identificados como Costa da Mina (nação mina ou gentio da Costa da Mina), dos quais uma proporção que suponho expressiva fosse provavelmente jeje, ou seja, falante de línguas gbe. Já aqueles positivamente identificados como jejes eram 21 indivíduos ( $22 \%$ da amostra), enquanto outros grupos de africanos ocidentais aparecem representados por apenas cinco nagôs, um tapa, um haussá e um cotocori. Esses dados indicam a importância numérica do contingente jeje, predomínio que adquire maior significância quando indagamos a composição das mesas diretoras da irmandade. ${ }^{14}$

Contudo, não é possível falar, para qualquer período que seja, de exclusividade étnica jeje, pois, como ficou evidente, sempre houve entre os irmãos representantes de várias nações. Todavia, uma divisão dos dados para os anos 1805-1830 e 1831-1855 sugere que a diversidade étnica aumentou no segundo período. Por exemplo, quatro dos cinco nagôs e três dos quatro angolas correspondem ao segundo período. Assim, pode-se concluir que a identidade étnica jeje não era condição necessária para o ingresso na sociedade, mas funcionava como um importante elemento facilitador.

Outro aspecto notável é que, em geral, os africanos pertenciam a mais de uma irmandade. Esse fato relativiza qualquer caracterização da IBJNR como um grupo corporativo fechado, sendo que seus membros podiam coordenar seus interesses comuns, a partir tanto dessa confraria quanto de outras. Contudo, na primeira metade do século XIX, a IBJNR era uma das três irmandades de africanos mais importantes da cidade. A do Rosário da Baixa de Sapateiros e a de São Benedito no convento de São Francisco eram as outras duas mais populares e nelas os jejes tinham participação expressiva. A do Rosário, da igreja vizinha da Conceição da Praia, tinha também a predileção dos irmãos do Corpo Santo. ${ }^{15}$ Apesar dessa pluralidade de opções e da circulação dos africanos por múltiplas irmandades, o que tentarei mostrar é que, em certos momentos, a IBJNR parece ter agregado em seu entorno uma rede social com interesses diferenciados, na qual a lógica profissional e mercantil pode ter prevalecido sobre a lógica étnica ou religiosa, na dinâmica associativa.

\footnotetext{
${ }^{14}$ Para além da mesa diretora de 1808 (Tabela 2), dos 26 membros da mesa diretora de 1830, consegui identificar a etnia de 9 deles - 2 minas e 7 jejes: APEB, Judiciário, Livro de Notas n. 236, f. 139.

${ }^{15}$ Agradeço a Maria Inês Cortes de Oliveira pela lista nominal dos africanos com testamento no período de 1800 a 1888 e pela quantificação de sua filiação às diversas irmandades. De um universo de 144 testadores membros de irmandades, 66 (ou 46\%) nomearam a IBJNR. Só 1 desses 66 africanos pertencia exclusivamente à IBJNR; o resto pertencia a 2 ou mais irmandades.
} 
Como foi dito, a proposta deste texto é ir além das estatísticas quantitativas, almejando uma aproximação mais particular, que ilumine os perfis biográficos desses africanos e seus laços sociais. No livro de compromisso de 1778 preservado no Arquivo da Cúria, constam duas listas dos mesários, uma delas impressa num termo datado em 13 de abril de 1776, no qual os irmãos se obrigavam a prestar contas à Provedoria dos Resíduos e Capelas e a não reeleger tesoureiro, nem emprestar dinheiro a juros, e a outra, num termo de juramento datado de 8 de maio de 1779, manuscrito na última página do mesmo livro.Encontrei, ainda, nos papéis avulsos da biblioteca da igreja da Conceição da Praia, uma prestação de contas do ano 1776-1777, realizada pelo tesoureiro José Machado Godinho. ${ }^{16}$ Os nomes e as assinaturas desses documentos permitiram elaborar a Tabela 1 .

Tabela 1. Mesários da Irmandade do Bom Jesus das Necessidades e Redenção, 1776-1779.

\begin{tabular}{|c|c|c|c|}
\hline & 13 de abril de 1776 & 1776-1777 & 8 de maio de 1779 \\
\hline Presidente & Felix Xavier Duarte* & $\begin{array}{c}\text { Francisco Nunes de } \\
\text { Moraes }\end{array}$ & João Nunes* \\
\hline Escrivão & Antonio José de Castro & José da Penha Ferreira & $\begin{array}{c}\text { Capelão Antonio Siqueira } \\
\text { Torres }\end{array}$ \\
\hline Tesoureiro & João Nunes* & $\begin{array}{l}\text { José Machado } \\
\text { Godinho }\end{array}$ & - \\
\hline Procurador & $\begin{array}{l}\text { José Veríssimo da Silva } \\
\text { Alexandre Pensa }\end{array}$ & $\begin{array}{l}\text { Ignácio Xavier } \\
\text { Ventura Mendes }\end{array}$ & D. José Álvares da Cunha \\
\hline Consultor & $\begin{array}{c}\text { Caetano Antonio } \\
\text { Monção } \\
\text { Luciano Ferreira de Sá* } \\
\text { João Corrêa da Costa* } \\
\text { Thomé Corrêa da Costa } \\
\text { José Francisco da Sena } \\
\text { Cristovão Teixeira da } \\
\text { Mata } \\
\text { Luiz Barboza } \\
\text { João Gomes Foguinho }\end{array}$ & $\begin{array}{c}\text { Felix Xavier Duarte* } \\
\text { Capitão Damásio Nunes } \\
\text { José Antunes } \\
\text { José Francisco da Cruz } \\
\text { Antonio [Roi]z [...]yro } \\
\text { José Miz [Martins] } \\
\text { Antonio de Azevedo } \\
\text { Felipe [?]g[os?] }\end{array}$ & $\begin{array}{c}\text { Felix Xavier Duarte* } \\
\text { Luciano Ferreira Bettancourt } \\
\text { Sá* } \\
\text { João Correia da Costa* } \\
\text { Antonio da Cruz e Souza } \\
\text { Joaquim Rabello de [?] } \\
\text { Miguel da [e?] + [?za] } \\
\text { Siprianno + Francisco } \\
\text { Antonio Pereira de Afonseca } \\
\text { Francisco da Chagas } \\
\text { Antonio de Araujo e Aragão } \\
\text { Antonio Joaquim da [Costa?] } \\
\text { Ignácio de Jezus } \\
\text { Paulo Ventura de Almeida }\end{array}$ \\
\hline
\end{tabular}

*Personagens que se repetem em várias colunas.

Fonte: Arquivo da Cúria Metropolitana de Salvador, "Bom Jesus das Necessidades e Redempção”, 1778; Biblioteca da Igreja da Conceição da Praia, papéis avulsos, 1777.

Observa-se que quatro dos mesários listados em 1776 (marcados com *) continuavam na cúpula do poder três anos depois, em 1779, com destaque para o presidente, e depois consultor, Xavier Duarte, e o tesoureiro, e depois

${ }^{16}$ Cabe notar que, contra a proibição do termo de 1776, de não "reelegerem na mesa de sua irmandade tesoureiro algum”, o antigo tesoureiro João Nunes tinha sido substituído por José Machado Godinho. 
presidente, João Nunes. Como já foi dito, há um vazio documental problemático entre 1780 e a primeira década do Oitocentos. Porém, numa portaria, datada de 9 de abril de 1808, em que os irmãos dão poderes ao tesoureiro Ignácio de Sampaio "para que possa fazer todas as despesas concernentes a festividade da IBJNR e pagar alguma dívida", figuram os nomes da mesa diretora daquele ano, conforme a Tabela 2 .

Tabela 2. Mesários da Irmandade do Bom Jesus das Necessidades e Redenção, 1808.

\begin{tabular}{lccc} 
& 9 de abril de 1808 & Nação & Ofício \\
Presidente & Joaquim Cardoso da Costa & Jeje & Barbeiro/músico/capitão \\
\hline Escrivão & João Gomes Touquinho & Jeje & - \\
Tesoureiro & Ignácio de Sampaio [S. Payo] & Jeje & Barbeiro/músico \\
Procurador & Manoel [Fraco] de Sta Anna & - & - \\
Consultores & Francisco Nunes de Moraes & Jeje & Barbeiro/músico \\
& Francisco da Silva Guerra & Jeje & Marceneiro? \\
& José Gomes da Conceição & Costa de Leste & Sapateiro \\
& Agostinho Maciel & Jeje & - \\
& Thomas Cuadrado & Jeje & Barbeiro \\
& [Mais dois nomes ilegíveis] & - & - \\
\hline
\end{tabular}

Fonte: Para a lista de irmãos - Biblioteca da Igreja da Conceição da Praia, papéis avulsos, 1808. Para a identificação étnica: Arquivo Público do Estado da Bahia (APEB), Livros de testamentos e inventários; Arquivo da Cúria Metropolitana de Salvador, Livros de óbito e batismo. Para o ofício - outras fontes.

Trinta anos depois de sua fundação, dois membros das mesas na década de 1770, João Gomes Touquinho (Foguinho) e Francisco Nunes de Moraes, continuavam a ocupar cargos na diretoria da irmandade. Aliás, outros dois africanos presentes nos anos 1770, José da Penha Ferreira e João Nunes, foram presidentes em 1805 e 1807, respectivamente. Isso indica a persistência, durante mais de três décadas, de uma rede de libertos africanos, a maioria deles jejes e, como veremos, com patentes militares, que tinha a capela do Corpo Santo como ponto de convergência.

Entre esses nomes, privilegiei aqueles que aparecem em ambas as décadas de 1770 e 1800. Com o intuito de melhor entender suas relações, utilizei a metodologia da "ligação nominativa", ou o cruzamento de séries documentais diferentes a partir da conexão estabelecida pelos nomes das pessoas que aparecem associadas a um determinado indivíduo. Essa metodologia foi complementada com a das "biografias coletivas", que privilegia a compreensão das interconexões entre a trajetória de vários indivíduos. ${ }^{17}$ Nessa abordagem, foi de especial interesse a figura de João Nunes da Silva, um dos nódulos centrais dessa rede nominal.

\footnotetext{
${ }^{17}$ Para o método onomástico proposto pela micro-história italiana: Robert Slenes, Na senzala uma flor. Esperanças e recordações na formação da família escrava - Brasil Sudeste, século XIX, Rio de Janeiro, Nova Fronteira, 1999; Walter Fraga Filho, Encruzilhadas da liberdade: histórias de escravos e libertos na Bahia (18701910), Campinas, Editora da Unicamp, 2006. Para o cruzamento da micro-história com a história atlântica e a metodologia de "biografias coletivas": Lara Putnam, "To study the fragments as hole: micro history and the Atlantic world", Journal of Social History, 2006, p. 615-630.
} 


\section{João Nunes e as conexões atlânticas da irmandade}

João Nunes era originário da Costa da Mina, foi batizado na igreja matriz da freguesia do Pilar e libertou-se da escravidão pagando 120 mil réis a seu senhor, Jerônimo Nunes Silva. No testamento, redigido em 1807, Nunes declarava que, antes de casar, teve "de tratos ilícitos" com a preta mina Josefa Gonçalves dos Santos uma filha por nome Feliciana Gonçalves, ambas falecidas, deixando uma neta, Thereza de Oliveira. ${ }^{18}$ Já liberto, em julho de 1766, ele casou na igreja, na vila de Cachoeira, com Francisca Ribeira da Cruz, também mina, tendo ambos, anteriormente, morado na freguesia da Conceição da Praia, em Salvador. Dessa união, não houve descendência. ${ }^{19}$

Um ano antes do casamento, em 1765, foi instituída, no convento do Carmo da Vila de Cachoeira, a irmandade do Senhor Bom Jesus dos Martírios, "erigida pelos homens pretos de nação Gege”. Não seria impossível que o liberto Nunes participasse dessa iniciativa, como não seria impossível que houvesse alguma conexão e continuidade entre a irmandade dos Martírios de Cachoeira e a da Redenção do Corpo Santo. ${ }^{20}$

Seja como for, em 1773, um ano antes da fundação da IBJNR, Nunes recebeu patente de ajudante de entradas e assaltos da freguesia de Santana, indicando que o casal estava de volta em Salvador. ${ }^{21}$ Naquela década, ele adquiriu certa notoriedade social, como atestam sua participação como padrinho em diversos batismos de cativos e seus cargos de tesoureiro e presidente da IBJNR, em 1776 e 1779, respectivamente..$^{22} \mathrm{Em} 1785$, o casal pede emprestados 340 mil réis e, para isso, hipotecam cinco cativos (Francisco jeje, Manoel angola, Antonio nagô, Ignácia crioula e Manoel crioulo) e "as benfeitorias com todos seus acessórios [...]". ${ }^{23}$ Esse patrimônio sugere uma relativa prosperidade, mas desconfio que, a partir de então, a vida de Nunes tomou outros rumos.

Em 1807, o já viúvo e ancião João Nunes residia na freguesia de Santana. Naquele ano, fora eleito presidente da IBJNR de novo e, por volta do fim de setembro, estava prestes a partir para Luanda, reino de Angola, junto com o

\footnotetext{
${ }^{18}$ APEB, Judiciário, 05/2048/2519/17, "Inventário e testamento de João Nunes", 1808, f. 4, 4v. Essa neta foi nomeada herdeira com a outra filha, Maria da Conceição Nunes, filha da escrava Catharina.

${ }^{19}$ ACMS, Cachoeira, Livro de Casamento 1765-85, cx. 34, Est. 3, f. 13v. Nesse registro de casamento, figura como senhor de Nunes o "capitão João Nunes Silva já defunto" (grifo do autor), quando no testamento consta "Jerônimo" Nunes Silva. Pode ser um erro do escrivão, mas talvez reflita a pertença consecutiva a dois senhores.

${ }^{20} \mathrm{~A}$ irmandade do Bom Jesus dos Martírios de Cachoeira, que, como a do Corpo Santo, excluía os crioulos, usava o mesmo vestuário de capa branca e murça vermelha, com "uma tarja feita de letras ou pintada, e dentro desta gravada a cruz do Senhor com todas as insígnias dos martírios que padeceu pelo gênero humano". Os irmãos da IBJNR utilizavam uma pequena cruz de juro por armas, de metal branco. Apesar dessa semelhança, a irmandade de Cachoeira celebrava sua festa em 15 de janeiro e a procissão no Domingo de Ramos, enquanto a de Salvador realizava a procissão em 3 de maio, no Dia das Cruzes, evocando também o martírio de Jesus Cristo. Para a irmandade de Cachoeira: AHU, Lisboa, Códice 1.666, "Compromisso da Irmandade do Senhor Bom Jesus com o soberano título de Senhor dos Martírios, erecta pelos Homens pretos de nasção Gege, neste Convento de Nossa Senhora do Monte do Carmo da Villa de Nossa Senhora do Rozario da Cachoeira, este anno de 1765"; apud Patricia Muvley, The black lay brotherhoods on colonial Brazil, Tese de doutorado, Columbia University, New York, 1976, p. 264-265.

${ }^{21}$ APEB, Colonial, maço 364-1, Livro de Patentes n. 25, f. 311-312.

${ }^{22}$ ACMS, Freguesia da Conceição da Praia, Livro de Batismos 1774-1786, ff. 19, 56, 63.

${ }^{23}$ Documento de leitura muito difícil: APEB, Judiciário, Livro de Notas n. 124, f. 333.
} 
seu confrade, o jeje Francisco da Silva Guerra, de 50 anos de idade, morador na Conceição. Eles viajariam no bergantim São Manoel Ativo, sob as ordens do capitão Bernardo da Silva Mindoens, um experiente marujo com várias viagens entre Bahia, Rio de Janeiro, Maranhão, Lisboa, Luanda e Benguela. O São Manoel Ativo realizaria o seu primeiro embarque de escravos em Luanda, em 10 de novembro de $1807 .^{24}$

Não sabemos se João Nunes regressou no mesmo navio que o levara a Angola, mas, um ano depois, em 4 de novembro de 1808, João Gomes Touquinho abria seu testamento e declarava que Nunes "faleceu da vida presente na cidade do Rio de Janeiro vindo de Benguela para esta cidade [Bahia]".25 Sabe-se que houve surtos de varíola em Luanda em 1805, 1807 e $1808 .{ }^{26}$ Porém, Francisco da Silva Guerra, seu companheiro de viagem, tinha regressado antes dessa data, pois aparece assinando a portaria da IBJNR em 9 de abril de 1808 (Tabela 2). Nesse momento, já estava empossado um novo presidente, talvez porque, diante da iminente celebração da procissão anual, em 3 de maio, as eleições foram adiantadas quando Guerra trouxe a notícia da morte de Nunes.

Antes de partir, João Nunes nomeara como "testamenteiros por aqueles estados em Benguela” Francisco da Silva Guerra, Alexandre Simão Pensa e o capitão Bernardo da Silva Mindoens. Na Bahia, ele indicou o já mencionado João Gomes Touquinho, assim como José Gomes da Conceição e Joaquim Cardozo da Costa. ${ }^{27}$ Note-se que, fora o capitão de navio, os outros cinco testamenteiros pertenciam à IBJNR, 2 deles (Touquinho e Pensa) já presentes em 1776 e 4 (Touquinho, Guerra, Cardoso da Costa e Gomes da Conceição) assinando na IBJNR em abril de 1808. Ou seja, estamos diante de um grupo que manteve relações de amizade e, provavelmente, comerciais, durante mais de três décadas em torno da irmandade. ${ }^{28}$ Touquinho, Conceição e Nunes eram também vizinhos na freguesia de Santana.

Nunes e Guerra iam, possivelmente, ao encontro de Alexandre Simão Pensa, descrito em 1807 como "homem preto morador em dita cidade de Benguela".29 Como Nunes, Pensa era originário da Costa da Mina e foi batizado na igreja do Pilar, na Bahia, vizinha à Praia. ${ }^{30}$ Como ele, era também miliciano e, em 1782, recebeu alvará de Sargento da Companhia dos Homens Pretos de

\footnotetext{
24The Trans-Atlantic Slave Trade Database Voyages, n. 48.548. Disponível em: <http://www.slavevoyages.org/ tast/database/search.faces>. Acesso em: 26 de abril de 2014; cf. Arquivo Histórico Nacional de Angola, Luanda, cod. 2.571. Agradeço a Lucilene Reginaldo pelas primeiras informações sobre esse capitão: comunicação pessoal, 24 de fevereiro e 13 de junho de 2003.

${ }^{25}$ APEB, Judiciário, O5/2048/2519/17, "Inventário e testamento de João Nunes", 1808, f. 3.

${ }^{26}$ Manolo Florentino; Alexandre Vieira Ribeiro; Daniel Domingues da Silva, "Aspectos comparativos do tráfico de africanos para o Brasil (séculos XVIII e XIX)", Afro-Ásia, n. 31, 2004, p. 106.

${ }^{27} \mathrm{APEB}$, op cit., f. 4v. Mattoso considera Nunes apenas um "marinheiro", o que me parece uma simplificação da personagem: Kátia Mattoso, Bahia: século XIX - uma província no Império, Rio de Janeiro, Nova Fronteira, 1992, p. 626.

${ }^{28}$ Nunes e Conceição eram ambos irmãos de São Benedito no convento de São Francisco, do Rosário da Baixa dos Sapateiros e do Rosário da Praia. Touquinho era também do Rosário da Baixa de Sapateiros, mas o que os unia a todos era a IBJNR.

${ }^{29} \mathrm{APEB}$, op cit.

${ }^{30}$ Arquivo do Arcebispado de Luanda (AAL), Benguela, Livro de Óbitos, 1797-1831, f. 60. Agradeço a Mariana Cândido por fornecer cópia desse registro.
} 
Pirajá, freguesia limítrofe a Salvador. ${ }^{31}$ Num registro municipal de 1790, seu nome aparece sob a rubrica de "lenhas", indicando ser fornecedor de madeira ou serrador. ${ }^{32}$ Pensa deve ter se retirado para Benguela na última década do século, coincidindo com a expansão comercial daquele porto. Da sua experiência na África, pouco sabemos, mas lá faleceu em 3 de abril de 1808, no mesmo período que João Nunes, talvez ambos vítimas da mesma epidemia de varíola. ${ }^{33}$ A pergunta que se coloca é: quais seriam os negócios daqueles africanos minas em terras angolanas?

\section{Estamos diante de um grupo que manteve relações de amizade e, provavelmente, comerciais, durante mais de três décadas em torno da irmandade}

Não era a primeira vez que João Nunes viajava aos "estados de Loanda, reino de Angola", pois, no testamento, declarava ser irmão da irmandade de Santo Antonio de Cathalagerona em Benguela. ${ }^{34}$ Aliás, numa relação sobre os moradores dessa cidade de 1797, ele é descrito como dono de uma taverna no porto daquela vila, onde seguramente comerciava cachaça importada da Bahia. Esses eram lugares privilegiados para o negócio da compra e venda de escravos, atividade em que Nunes presumivelmente esteve envolvido. Ele é referido também como ajudante ou soldado dos Henriques e, nessa qualidade, é provável que participasse em campanhas de conquista e captura de cativos por aquelas terras, embora disso não existam maiores informações. ${ }^{35}$ Sua pertença a essa tropa de milicianos negros, atuante no mundo atlântico lusófono, dava continuidade ao já mencionado cargo de ajudante de entradas e assaltos. Décadas depois, ao morrer, ele ainda guardava "uma farda de pano azul forrada de cetim carmesim com dragonas de galão de ouro e avivada do mesmo com um colete de cetim branco bordado", talvez seu uniforme dos Henriques (Figura 2).$^{36}$ Assim, merece destaque a atividade militar de Nunes e o seu paralelo envolvimento no comércio e no tráfico de escravos, traços que surgem como característicos de vários outros irmãos da IBJNR.

\footnotetext{
${ }^{31}$ APEB, Colonial, maço 369, Livro de Patentes n. 30, f. 189.

${ }^{32}$ Arquivo Municipal de Salvador (AMS), Livro de Oficinas 1790-1813, f. 21

${ }^{33}$ AAL, Benguela, Livro de Óbitos 1797-1831, f. 60.

${ }^{34}$ Sobre essa irmandade, ver Lucilene Reginaldo, Os Rosários dos Angolas: irmandades de africanos e crioulos na Bahia setecentista, São Paulo, Alameda; Fapesb, 2011, p. 136-138

${ }^{35}$ Mariana Cândido, An African slaving port and the Atlantic world. Benguela and its Hinterland, Cambridge, Cambridge University Press, 2013, p. 127, 166; cf. IGHB, DL 32, 02.02: "Relação de Manuel José da Silveira Teixeira sobre os moradores da cidade de São Felipe de Benguela", 27 de novembro de 1797, f. 9v. Agradeço a Mariana Cândido por fornecer transcrição desse registro. AHU, Angola, caixa 89, doc 67, 21 de dezembro de 1798

36Judiciário, 05/2048/2519/17, "Inventário e testamento de João Nunes”, 1808 (partilha). Sobre os Henriques baianos, ver, entre outros, Hendrik Kraay, "Identidade racial na política, Bahia, 1790-1840: o caso dos Henriques", In: István Jancsó (org.), Brasil: formação do Estado e da nação, São Paulo; ljuí, Hucitec; Unijuí; Fapesp, 2003, p. 521-546
} 


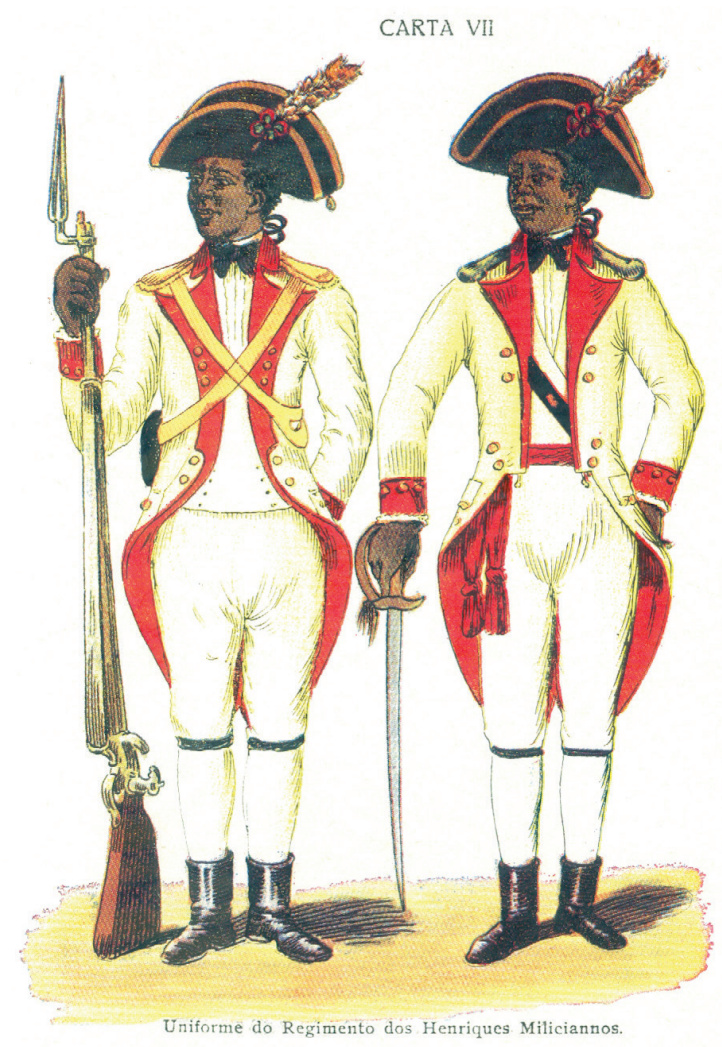

Figura 2. Uniforme do regimento dos Henriques Milicianos. Fonte: Luis dos Santos Vilhena, A Bahia no século XVIII, Salvador, Itapuã, 1969, vol. 1, carta 7.

Na mesma relação de 1797, João Nunes aparece morando com a forra Juliana e o filho mulato desta, Manoel, de sete anos, provavelmente seus dependentes, e como dono de seis escravos, dois homens - Miguel, aprendiz de tanoeiro, e Francisco, barbeiro - e quatro mulheres: Catharina, Anna, Quitéria e Florinda. ${ }^{37}$ Nunes foi amasiado com Catharina, de nação benguela, com quem, naquele período, teve uma filha, Maria da Conceição Nunes, cega, nomeada, anos depois, junto com a neta Theresa, sua herdeira. A preta Anna, também de nação benguela, era cativa de longa data, pois já trabalhava no ganho para ele em Salvador, pelo menos desde 1789, conforme atesta a licença municipal que ele solicitou para ela vender na rua. Quando Nunes libertou Anna, provavelmente de volta em Salvador, ele preservou "a carta de alforria dela junto com a sua, sugerindo que viveram como marido e mulher ou que ele não queria que outro ficasse com a renda dela" ${ }^{38}$ Anna teve duas filhas crioulinhas, Eugenia e Maria, as quais ele deixou forras no testamento de 1807. Outro escravo mencionado nesse documento era João, também de nação benguela, ainda moleque, aprendiz de serrador. Ausente no testamento, aparece na partilha o escravo

${ }^{37}$ IGHB, DL 32, O2.02, "Relação de Manuel José da Silveira Teixeira sobre os moradores da cidade de São Felipe de Benguela", 27 de novembro de 1797, f. $9 \mathrm{v}$.

${ }^{38} \mathrm{AMS}$, 88, Licenças 1789, f. 211 apud Richard Graham, Alimentar a cidade. Das vendedoras de rua à reforma liberal (Salvador 1780-1860), São Paulo, Companhia das Letras, 2013, p. 94; 357 (nota 6). 
Domingos, provavelmente benguela, mas nomeado nesse documento, como o mesmo João, "angola”. Domingos é descrito como "moleque ainda boçal", o que indicaria sua chegada recente na Bahia, talvez após a morte do senhor, pela mão de Guerra. ${ }^{39}$

O movimento ascendente do tráfico entre Salvador e Benguela teve início por volta de 1775. Entre 1781 e 1789, atingiu uma média de 6 mil escravos anuais. Nesse período, chegaram à Bahia 38 barcos desse porto, 29 de Luanda, 3 de Loango e 1 de Cabinda. O tráfico com Benguela experimentou um aumento significativo entre 1792 e 1796, com uma média de 10 mil escravos anuais. ${ }^{40}$ O incremento de cativos benguelas na última década do século XVIII, período em que Nunes esteve por lá, reflete-se na demografia escrava do Recôncavo e em outros espaços, como a Irmandade do Rosário de João Pereira, que, em 1784 , dividia a mesa diretora entre jejes e benguelas. ${ }^{41}$

Com a viagem de 1807, Nunes poderia estar tentando fortuna de novo. Com um empréstimo de 600 mil réis, ele comprou os "efeitos que levo na minha companhia na embarcação [...]", esperando pagar a dívida na sua volta, "pelos produtos da minha carregação". Caso não fosse suficiente, deixava hipotecadas suas duas casas de moradia na rua direita da Saúde, na freguesia de Santana. Ele declarava também ser devedor a sua "comadre" e "senhora" Izabel Monteira da quantia de 50 mil réis que "em dinheiro lhe emprestou sem clareza [recibo] alguma". ${ }^{42}$ Com um capital inicial que correspondia, na Bahia, ao preço de venda de quatro escravos adultos, qual seria a "carregação" que pretendia trazer de Angola? A presença na partilha do moleque Domingos é um indício.

O caso de Nunes e seus amigos da IBJNR sugere
que, em combinação com outras mercadorias, eles
investiam no trato negreiro, privilegiando nesse
período os cativos benguelas

O caso de Nunes e seus amigos da IBJNR sugere que, em combinação com outras mercadorias, eles investiam no trato negreiro, privilegiando nesse período os cativos benguelas, mas nada permite aventar que tivessem o capital suficiente para um envolvimento em grande escala. O notório, porém, é a existência de conexões mercantis entre a Bahia e Angola estabelecidas por africanos minas e jejes, milicianos e ligados à IBJNR. A pertença de Nunes nessa irmandade

\footnotetext{
39APEB, Judiciário, 05/2048/2519/17, “Inventário e testamento de João Nunes”, 1808 (partilha).

${ }^{40}$ Autoria não referida, "Um documento inédito da história do tráfico negreiro", Afro-Ásia, n. 1, p. 124. Para o início desse movimento em 1775: Lucilene Reginaldo, Os Rosários dos Angolas: irmandades de africanos e crioulos na Bahia setecentista, São Paulo, Alameda; Fapesb, 2011, p. 308; cf. AHU, cx. 54, doc. 11.

${ }^{4}$ Luis Nicolau Parés, A formação do Candomblé. História e ritual da nação jeje na Bahia, Campinas, Editora da Unicamp, 2006, p. 65; 66; 68; APEB, Cartas ao Governo, 1780-84, maço 176, "Parecer do desembargador ouvidor Geral do Crime a d. Rodrigo José Nunes, 9/11/1784"; apud João José Reis, A morte é uma festa, São Paulo, Companhia das Letras, 1991, p. 56.

${ }^{42} \mathrm{APEB}$, op cit., f. 5.
} 
e na de Santo Antonio de Cathalagerona em Benguela indica a possibilidade de essas associações terem funcionado, para além da devoção religiosa, como "sociedades" de ajuda mútua num contexto comercial atlântico. Cabe reiterar que, em 1807, João Nunes viajava a Angola quando era presidente da IBJNR. ${ }^{43}$ Teria sua viagem alguma ligação com esse cargo, ou os negócios eram de caráter estritamente pessoal?

Na África central, instituições religiosas como o culto Lemba tinham essa dupla função de providenciar recursos espirituais e de interligar uma elite econômica mediante rotas comerciais que atravessavam regiões etnicamente diversificadas e, às vezes, em conflito. ${ }^{44} \mathrm{~A}$ sociedade Ekpe no delta do Níger, no século XIX, e sua réplica cubana, a sociedade Abakuá, parecem ter exercido uma função semelhante..$^{45} \mathrm{~A}$ irmandade católica como rede de solidariedade comercial transregional e, inclusive, transatlântica apresenta-se como um interessante desdobramento da funcionalidade dessas instituições e, quem sabe, como uma forma de africanização das mesmas. ${ }^{46}$

\section{Capitães, barbeiros, sangradores e músicos}

José da Penha Ferreira foi outro dos irmãos que manteve vínculo com a IBJNR ao longo das décadas. No ano de 1777, ele foi escrivão (Tabela 1) e, quase 30 anos depois, em 1805, foi presidente, aparecendo ainda, no final da sua vida, em 1823, como procurador geral. ${ }^{47}$ Nas irmandades de pretos setecentistas, o cargo de escrivão era geralmente ocupado por brancos, mas José da Penha era natural da Costa da Mina. Ele teria aprendido a ler e a escrever ainda criança, pois chegou à Bahia com seis meses de idade, em $1753 .{ }^{48}$ Junto com sua mãe, batizada como Isabel, foi comprado por Braz Ferreira da Penha e sua mulher, Josefa Gomes. Falecendo o dito senhor, a viúva casou de novo com o preto Felix Xavier Duarte, que, por sua vez, foi presidente da IBJNR em 1776 e consultor nos anos seguintes. ${ }^{49}$

O forro Felix Xavier Duarte recebeu patente de capitão de entradas e assaltos do distrito de Rio Vermelho em 1773, o mesmo ano em que seu confrade Nunes foi nomeado ajudante..$^{50}$ Ele já estava casado em 1776 e, em dezembro de

\footnotetext{
${ }^{43}$ APEB, Judiciário, 05/2048/2519/17, “Inventário e testamento de João Nunes”, 1808, f. 5 v, 6.

${ }^{44}$ John M. Janzen, Lemba, 1650-1930: a drum of affliction in Africa and the New World, Nova York; London: Garland Publishing Inc., 1982.

45Stephan Palmié, "Ekpe/Abakua in Middle Passage", In: Andrew Apter; Lauren Derby, Activating the past history and memory in the black Atlantic world, Cambridge, Cambridge Scholars Publishing, 2010, p. 1-44.

${ }^{46}$ Ver Lucilene Reginaldo, "Travessias, trânsitos e conexões de Lepanto à Kalunga: irmandades e devoções negras em Portugal, na América portuguesa e em Angola no século XVIII”, texto apresentado na conferência Africanos nas Américas: reconstruindo vidas num Novo Mundo, 1675-1825, University of the West Indies, Barbados, 14 a 16 de março de 2013.

${ }^{47}$ Ele aparece referido como procurador geral: "Tombo dos bens das Ordens Terceiras, Confrarias e Irmandades da Cidade do Salvador em 1853”, Publicações do Arquivo do Estado da Bahia, vol. 7, Salvador, Imprensa Oficial, 1948, p. 89.

${ }^{48} \mathrm{Em}$ janeiro de 1823, ele é descrito como tendo 70 anos: ACMS, Freguesia de São Pedro, Livro de Óbitos 1795-1823, f. 195. A idade de seis meses para a chegada à Bahia consta no testamento.

49"Testamento de José da Penha Ferreira, 1810": APEB, Judiciário, Processo Cível 87/3099/16, "Irmandade Bom Jesus das Necessidades e Redenção contra Agostinha Romana de Vargas”, 1846-1850, ff. 67ss.

${ }^{50}$ APEB, Colonial, maço 364-1, Livro de Patentes n. 25, f. 360.
} 
1784, comprou com sua mulher - nesse documento, nomeada Josefa Gomes da Costa - uma morada de casas de sobrado, sitas na rua que ia da Quitanda Velha para o hospício de Jerusalém, por 500 mil réis. ${ }^{51}$ Nessas duas décadas, ele apadrinhou e foi senhor de vários escravos..$^{52}$ Fora isso, a figura de quem provavelmente foi um dos fundadores da IBJNR permanece elusiva e enigmática. Mas, voltando a José da Penha, sabemos que sua senhora Josefa lhe passou carta de liberdade, gratuitamente, ainda em vida de Duarte. ${ }^{53}$

Dessa informação, depreende-se que a IBJNR admitiu como irmão o filho liberto de uma escrava pertencente à esposa do presidente. Não apenas admitiu, mas colocou num posto de alta responsabilidade quando tinha apenas vinte e poucos anos, provavelmente pelo seu domínio das letras. No ano seguinte, ele foi substituído pelo padre capelão do Corpo Santo, presumivelmente branco, o que sugere a dificuldade da irmandade em achar africanos para ocupar o cargo de escrivão. Contudo, José da Penha não parece ter desperdiçado as oportunidades de uma boa educação. Em 1796, ele aparece na lista de irmãos do Rosário da Baixa dos Sapateiros como "capitão": mais uma alusão a atividades militares dos irmãos da IBJNR. ${ }^{54}$

O título de capitão se presta à ambiguidade, pois podia referir-se a um capitão de mar, um capitão de tropa militar, um capitão de entradas e assaltos ou, ainda, a um capitão de "canto" ou grupo de trabalho, composto de carregadores e escravos de ganho. Entre as tropas urbanas, havia o já mencionado Terço dos Henriques, composto de pretos forros. ${ }^{55}$ Porém, o maior contingente de capitães negros parece ter sido de capitães de entradas e assaltos. Embora comandados por um capitão e um sargento-mor brancos, "todo o mais corpo são pretos, com patentes unicamente de capitães". Em tempo de guerra, eles exploravam "as campanhas, estradas e marinhas" e atuavam como mensageiros levando ordens e cartas; em tempo de paz, eram usados "para darem caça e prenderem os escravos fugitivos, de que se formam temíveis quilombos, bem como para seguirem, à maneira dos empresadores nas monterias [perseguição], os presos que muitas vezes sucede escaparem das prisões". Ou seja, os capitães de entradas e assaltos eram os temidos capitães do mato. ${ }^{56}$ Não sei em que categoria se encaixava Penha, mas a recorrência de capitães de entradas e assaltos e membros dos Henriques entre os irmãos da IBJNR não pode ser negligenciada. A convergência da elite da irmandade com a elite dos milicianos negros, sobretudo no que diz respeito aos fundadores na década de 1770 ,

51ACMS, Freguesia da Conceição da Praia, Livro de Batismos 1774-1786, f. 68. APEB, Judiciário, Livro de Notas n. 125, f. 206. Existe outra escritura de compra e venda de 1791, que não foi possível consultar por estar fora de uso: APEB, Judiciário, Livro de Notas n. 129, f. 249.

52/dem, Freguesia da Conceição da Praia, Livro de Óbitos 1781-1814, f. 10v; Livro de batismos 1774-1786, ff. 68, 96. 53“"Testamento de José da Penha Ferreira, 1810”: APEB, Judiciário, Processo Cível 87/3099/16, "Irmandade Bom Jesus das Necessidades e Redenção contra Agostinha Romana de Vargas", 1846-1850, ff. 67ss.

${ }^{54}$ Arquivo da Irmandade de Nossa Senhora do Rosário da Baixa dos Sapateiros (AINSRBS), Livro de Irmãos n. 1, f. 216v.

${ }^{55}$ Sobre as milícias negras, ver: Hendrik Kraay, Race, State and Armed Forces in Independence-Era Brazil: Bahia, 1790s-1840s, Stanford, Stanford University Press, 2001.

${ }^{56}$ Luis dos Santos Vilhena, A Bahia no século XVIII, vol. 1, Salvador, Itapuã, 1969, p. 246. Sobre os capitães de mato, ver os capítulos de Silvia Hunold Lara e Luiz Mott em João José Reis; Flávio dos Santos Gomes (orgs.), Liberdade por um fio, São Paulo, Companhia das Letras, 1996. 
permite argumentar que a constituição da irmandade foi resultado da iniciativa e do espírito corporativo desse grupo profissional. ${ }^{57}$

Outra característica marcante é que vários desses capitães e milicianos atuavam como barbeiros e regentes de orquestras de barbeiro. Sabe-se que, no Brasil colônia, os barbeiros podiam exercer funções de cirurgiões ou médicos, obtendo licença para "sangrar, sarjar, lançar ventosa e sanguessugas", podendo alguns deles aplicar também sudoríficos, tirar dentes ou preparar remédios e curativos como purgantes. ${ }^{58}$ Igualmente, nas tendas de barbeiro, eles amolavam ferramentas, desde navalhas até armas. ${ }^{59}$ Sem dúvida, a familiaridade com a navalha e as práticas de cura podiam aproximar alguns desses barbeiros sangradores do universo religioso do Candomblé. ${ }^{60}$

Vários deles também combinavam essas habilidades com a de músicos ou mestres de bandas de música de barbeiro. Nas irmandades, era comum a participação de músicos nas procissões, nas festas anuais, na petição de esmolas, nos cortejos do viático etc. ${ }^{61}$ Por exemplo, no compromisso de 1765 da irmandade dos Martírios de Cachoeira, especifica-se que, no dia da festa, "haverá da porta da igreja para fora luminárias, roquerias, tambor, trombetas, e o mais que se pratica em qual função". Na IBJNR, no dia da procissão, em cada passo representando os martírios de Jesus Cristo, cantava-se "a música, seu verso como costuma" ${ }^{62}$ Em 1813, o viajante inglês James Prior, visitando Salvador, comentava que, enquanto na igreja celebravam a missa, do lado de fora, os tiros "de musquete, fogos de artifício, tambores, tamborins, clarinetas e gritos do povo formam um coro constante".63

Os instrumentos das bandas de barbeiro incluíam uma seção de sopros (trompas, clarinetes, pífanos e flautas), uma de metais (pratos) e uma de percussão (caixas e zabumbas) (Figura 3). Instrumentos de corda, como a rabeca

\footnotetext{
${ }^{57}$ Em 1780, José Machado Godinho (tesoureiro em 1777) foi nomeado cabo de esquadra da 2a Companhia do Terço dos Henriques: APEB, Colonial, maço 368, Livro de Patentes n. 29, f. 2. Entre irmãos que receberam patentes de capitão de entradas e assaltos: em 1790, Joaquim Cardoso da Costa (testamenteiro de João Nunes), em 1790, Luciano Ferreira de Bettencourt (consultor em 1779), em 1794, José Antonio d'Etra e, em 1793, Agostinho Freire: Arquivo Nacional da Torre do Tombo (ANTT), Lisboa, Registro Geral de Mercês de D. Maria I, liv. 21, f. 376v; liv. 22, f. 254v; liv. 25, f. 95v, 245v.

${ }^{58}$ AMS, Livro de Carta de Examinações e Officiaies, 1770-1807. Sobre o tema: Tania Salgado Pimenta, "Barbeiros-sangradores e curandeiros no Brasil (1808-28)", História, Ciências, Saúde - Manguinhos, vol. 5, n. 2 , 1998, p. 349-372; Jacimara Souza Santana; Andreilza Oliveira dos Santos, "Sangradores africanos na Bahia do Século XIX (1825-1828)", Sankofa, vol. 3, n. 6, 2010, p. 51.

${ }^{59}$ Ver, por exemplo, Jean Baptiste Debret, Boutique de barbier (“Tenda de barbeiro"), aquarela, 1821. Em Lisboa, os barbeiros se dividiam entre barbeiros de barbear e barbeiros de guarnecer espadas: Glaydson Gonçalves Matta, Tradição e modernidade: práticas corporativas e a reforma dos ofícios em Lisboa no século XVIII, Dissertação de mestrado, Universidade Federal Fluminense, Niterói, 2011, p. 40.

${ }^{60}$ Encontramos barbeiros como José Bernardino da Costa Faria, próximo às lideranças dos terreiros da Casa Branca e do Gantois, Francisco Nazaré e Marcos Rodrigues Soares do Gantois, ou José Joaquim de Moraes, que foi líder do terreiro do Bogum na década de 1860. Esse é tema para um artigo em andamento.

${ }^{6}$ Ver, por exemplo, Marieta Alves, "Música de barbeiros", Revista Brasileira de Folclore, vol. 7, n. 17, 1967, p. 5-13. ${ }^{62}$ Patricia Muvley, The black lay brotherhoods on colonial Brazil, Tese de doutorado, Columbia University, New York, 1976, p. 268-269.

${ }^{63}$ James Prior, Voyage along the Eastern Coast of Africa, to Mosambique, Johanna, and Quiloa to St. Helena to Rio de Janeiro, Bahia and Pernambuco in Brazil, in the Nisus Frigate, London, Sir Richard Phillips \& Co., 1819, p. 103 apud João José Reis, A morte é uma festa, São Paulo, Companhia das Letras, 1991, p. 61.
} 


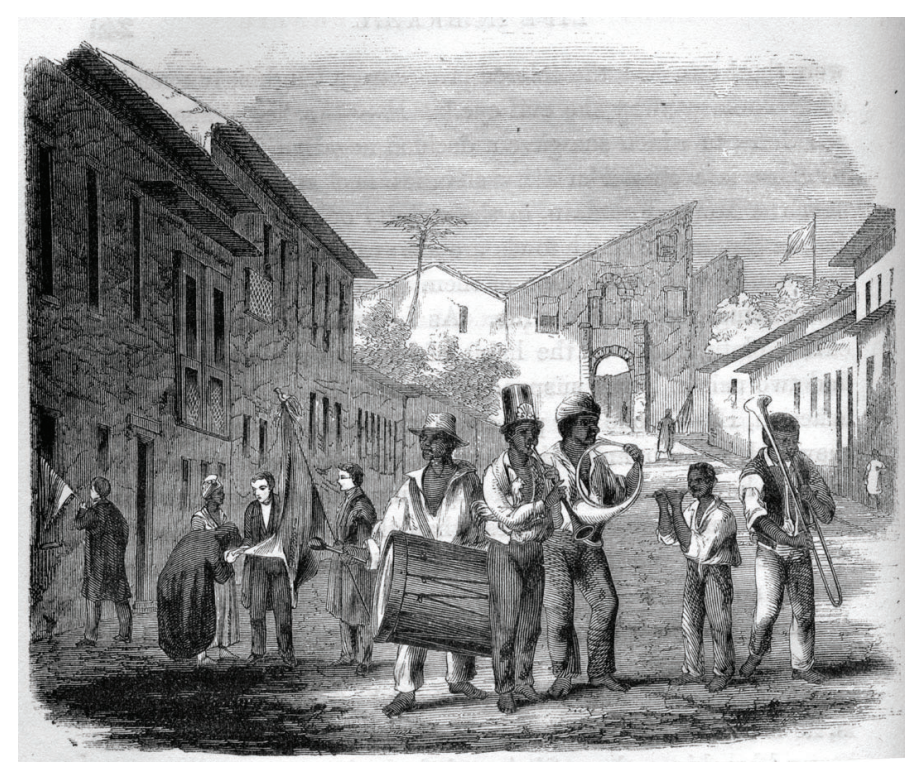

Figura 3. Pedindo esmola para a folia do Espírito Santo, com banda de música. Fonte: Thomas Ewbank, Life in Brazil (New York, 1856), p. 251 (copy in Special Collections Department, University of Virginia Library).

e o rabecão, também podiam integrar as bandas de barbeiro na Bahia. ${ }^{64}$ Mais difícil de imaginar é o tipo de música interpretado com esses instrumentos. Pensando no contexto religioso das irmandades, além de uma base rítmica de matriz africana, com afinidade ao batuque e ao lundu, pode-se pensar em outras influências, como, por exemplo, a música do barroco mineiro ou, talvez, a das marchas das bandas militares. ${ }^{65}$

Um dos irmãos da IBJNR que era barbeiro, mestre de orquestra e miliciano foi Francisco Nunes de Moraes. Esse "preto jeje” foi fiel à confraria ao longo do tempo, exercendo a função de presidente em 1777 e a de consultor em 1808 (Tabelas 1 e 2). Em 1773, ele já aparece como "mestre barbeiro"; em 1781, como regente de orquestra e ainda como barbeiro em $1790 .{ }^{66} \mathrm{Em} 1779$, recebeu alvará de trombeta-mor da cavalaria auxiliar de Salvador ${ }^{67}$ Foi escravo do capitão-mor Antonio Nunes de Moraes, "que por seu falecimento me libertou pela quantia de 250 mil réis". Morador na freguesia do Pilar, ele foi casado com a crioula Ifigênia Maria da Trindade, de cuja união nunca teve filhos. Moraes redigiu um primeiro testamento em 1790, mas anexou um codicilo em 1810,

\footnotetext{
${ }^{64}$ APEB, Livro de Testamentos n. 3, "Testamento de Francisco Nunes Morais", 1811, f. 35v; Livro de Testamentos n. 7, “Testamento de Joaquim Felix de Santana”, 1814, ff. 35-35v; Livro de Testamentos n. 30, "Testamento de Felipe Botelho", 1843, ff. 168ss.

${ }^{65} \mathrm{Na}$ década de 1860, a música do barbeiro Marcos é referida como "lundu", induzindo as pessoas a sambar, em festas como a Lavagem do Bonfim: "Na frente Marcos barbeiro/no zabumba vem tocando/um bem tangido lundú/e toda gente sambando": O Alabama, 20 de janeiro de 1866, p. 2-3. Ver ainda O Alabama, 22 de fevereiro de 1869, p. 3; 12 de janeiro de 1870, p. 4; 29 de janeiro de 1870, p. 6-7.

${ }^{66} \mathrm{ACMS}$, Freguesia do Pilar, Livro de Batismos 1771-1883, f. 37. A menção de regente provém do Arquivo da Santa Casa da Misericórdia de Salvador: Marieta Alves, "Música de barbeiros", Revista Brasileira de Folclore, vol. 7, n. 17, 1967, p. 11. AMS, Livro de Oficinas 1790-1813, f. 6.

${ }^{67}$ APEB, Colonial, maço 367, Livro de Patentes n. 28, f. 32.
} 
pouco antes de falecer em 13 de janeiro de 1811, com aproximadamente 80 anos de idade. Cabe notar que, entre as testemunhas assinando o codicilo, figurava Bernardo da Silva Mendoens, o capitão que levou João Nunes para Benguela. ${ }^{68}$

A documentação permite vislumbrar um processo bastante rápido de acumulação de riqueza e ascensão social. Enquanto em 1790 ele menciona apenas 2 escravos, aprendizes de músico (de rabeca e rabecão), em 1808 ele aparece como senhor de mais de 12 cativos, com a respectiva prole. Ele forrou a maioria, incluindo cinco "oficiais de barbeiro," membros da sua orquestra, sob a condição de acompanhar sua mulher até a morte. À crioula Petronila, concedia o enxoval e 100 mil réis, caso viesse a casar com "pessoa de bom procedimento". Ele ainda determinava repartir suas roupas de uso entre seus escravos. Percebe-se, assim, a figura de um patriarca poderoso, mas de trato relativamente benigno com seus dependentes. ${ }^{69}$

\section{A familiaridade com a navalha e as práticas de cura podiam aproximar alguns desses barbeiros sangradores do universo religioso do Candomblé}

Moraes deixou os instrumentos do ofício de barbeiro e de músico em poder da mulher "para os escravos tocarem neles e por morte dela serão repartidos por todos". Contudo, ele advertia, pedia e rogava "que todas as vezes que sair o nosso bom senhor [da Redenção], não estando eles em urgente ocupação, o acompanhem por ser assim de minha vontade". Embora sua orquestra também participasse das festas de Nosso Senhor do Bonfim, a referência ao "bom" senhor indicaria o envolvimento dela nas procissões da IBJNR. ${ }^{70}$

Moraes não era o único barbeiro e músico da IBJNR. Identifiquei pelo menos mais cinco irmãos compartilhando a profissão. O também capitão de entradas e assaltos, Damásio Nunes, consultor em 1777 (Tabela 1), em 1774 recebia uma insignificante quantia pelas "rebecas e atabales [timbales?]" tocados na porta da igreja. ${ }^{71}$ Outro era Ignácio de Sampaio, que aparece como músico ou regente

\footnotetext{
${ }^{68}$ APEB, Livro de Testamentos n. 3, "Testamento de Francisco Nunes Morais", 1811, ff. 34, 34v, 37-38. ACMS Freguesia do Pilar, Livro de Óbitos 1807-1824, f. 73. Kátia Mattoso comenta esse caso como exemplo de liberto abastado: Kátia Mattoso, "Testamentos de escravos libertos na Bahia no século XIX: uma fonte para o estudo das mentalidades”, In: ___. Da revolução dos Alfaiates à riqueza dos baianos no século XIX: itinerário de uma historiadora, Salvador, Corrupio, 2004 [1979], p. 248-249.

69/dem, Livro de Testamentos n. 3, “Testamento de Francisco Nunes Morais”, 1811, f. 34v, 37, 37v. Ver João José Reis, A morte é uma festa, São Paulo, Companhia das Letras, 1991, p. 99-100.

7o/bidem, f. 37v. "Havia na porta da capela [do Bonfim], nas noites das novenas e no dia da festa, tocata pela música de barbeiros do mestre Manuel [sic] Francisco Nunes de Moraes": José Eduardo Freire de Carvalho Filho, A devoção do Senhor do Bonfim e sua história, Salvador, Typ. de São Francisco, 1923. Francisco teve um escravo chamado Manoel, alforriado por verba testamentária (f. 37). Se o regente da banda fosse Manoel, indicaria um período posterior a 1811.

${ }^{71}$ Marieta Alves, "Música de barbeiros", Revista Brasileira de Folclore, vol. 7, n. 17, 1967, p. 11.
} 
de orquestra em 1789 e como barbeiro em $1790 .{ }^{72}$ Vinte anos depois, em 1810, esse preto jeje atuou como testemunha na testamentaria de João Nunes. Ele foi identificado como tendo aproximadamente 70 anos (nasceu, assim, por volta de 1740), casado, morador ao beco dos Aljubes (Algibebes), na freguesia da Conceição da Praia, "que vive da sua tenda de barbeiro".73 No testamento, redigido em 1805, ele declarava ter sido presidente da IBJNR e, no termo de 1808, ele aparece como tesoureiro (Tabela 2). Sampaio chegou à Bahia menor de idade, talvez por volta de 1750. Foi escravo do licenciado João Sampaio, mas, por morte deste, antes de 1776, comprou sua liberdade por 70 mil réis. ${ }^{74}$ Casou, antes de 1788, com Thereza Correa de Souza, uma preta jeje com quem, um ano antes das núpcias, teve uma filha, Brasília Correa de Sampaio. Ele teve vários escravos, dos quais conhecemos três que enterrou na igreja da Conceição da Praia (entre 1788 e 1800) e outros três que forrou no testamento, sob a condição de acompanhar a sua mulher até a morte. ${ }^{75}$ Ele também apadrinhou vários outros, indicando sua visibilidade social na comunidade africana. ${ }^{76}$

Nosso quarto barbeiro, também dono de banda de música e miliciano, foi Joaquim Cardoso da Costa, que, lembro, foi o segundo testamenteiro de João Nunes na Bahia. Joaquim aparece com presidente da IBJNR em 1808, em companhia do então consultor Nunes de Moraes e do tesoureiro Sampaio (Tabela 2). Ou seja, a cúpula da IBJNR, no início do Oitocentos, reunia os principais proprietários de bandas de barbeiro da cidade.

Joaquim Cardoso da Costa, como seus confrades, era liberto de nação jeje, morador na freguesia da Conceição da Praia, onde tinha sido batizado. Em 1786, ele já aparece como músico ou regente de orquestra de barbeiro e, em 1790, é listado como barbeiro. ${ }^{77}$ Esteve casado com Joaquina Maria da Conceição, "também natural da Costa", com a qual não teve filhos. Como a maioria dos libertos da irmandade, ele foi senhor de escravos; em 1803, aparece enterrando um deles, Simplício, jeje, de dez anos. ${ }^{78}$ Em 9 de dezembro de 1809, ele batizava mais 2 escravos: Felipa, nagô, de 30 anos, e a recém-nascida Joana, filha da cativa Maria. ${ }^{79}$ Os padrinhos foram, respectivamente, os africanos Francisco Moreira e Luis Campos; este, irmão da IBJNR, e aquele, casado com Rita Campos, também irmã da confraria. Observamos, assim, a superposição dos laços criados pela pertença à irmandade com as redes de compadrio.

\footnotetext{
${ }^{72}$ Marieta Alves, "Música de barbeiros", Revista Brasileira de Folclore, vol. 7, n. 17, 1967, p. 11. AMS, Livro de Oficinas 1790-1813, f. 6. No mesmo ano, ele aparece ainda sob a rubrica "louças" e, em 1792, Ignacio José [sic] de Sampaio aparece sob a rubrica de “lanchas”. AMS, Livro de Oficinas 1790-1813, ff. 14, 39

${ }^{73}$ APEB, Judiciário, 05/2048/2519/17, “Inventário e testamento de João Nunes, 1808”.

${ }^{74}$ ACMS, Freguesia da Conceição da Praia, Livro de Batismos 1774-1786, f. 66.

${ }^{75}$ APEB, Livro de Testamentos n. 11, "Testamento de Ignácio Sampaio", ff. 199-202. Para o enterro dos escravos: ACMS, Freguesia da Conceição da Praia, Livro de Óbitos 1781-1804, ff. 107, 127v, 223.

${ }^{76} \mathrm{Em}$ janeiro de 1780, por exemplo, ele foi padrinho de 6 escravos de Francisco José Gouvea: ACMS, Freguesia da Conceição da Praia, Livro de Batismos 1774-1786, ff. 201, 202v.

${ }^{77}$ Marieta Alves, op cit., f. 6

${ }^{78}$ ACMS, Freguesia da Conceição da Praia, Livro de Óbitos 1781-1804, f. 259v. Ele também enterrou a escrava Antonia, jeje, de 30 anos, em 21 de junho de 1807: Livro de Óbitos 1804-1810, f. 314v

${ }^{79}$ ACMS, Freguesia da Conceição da Praia, Livro de Batismos 1809-1815, f. 278v.
} 
Joaquim faleceu em 1826 e, no testamento redigido em 18 de maio, declarava possuir, entre seus "bens insignificantes", 10 escravos, 6 deles músicos. Joaquim, da Costa [da Mina], ele forrou e deixou-lhe "todo o tráfico da minha tenda de barbeiro, menos os instrumentos de música". ${ }^{80}$ Os músicos, todos moços, quatro moçambiques (Albino, Benedito, Francisco e Marcos) e dois nagôs (Vitorino e Quintino), ele coartou. Todos os instrumentos de música ficaram a cargo de Albino, "mestre de música de barbeiro [...] para ele com os outros usar", a fim de pagar as quantias em que foram coartados, "sem que por isso possa o dito escravo lucrar do trabalho dos outros coisa alguma”. A lista dos instrumentos incluía: "três clarinetes travesseiros, duas ditas portugueses, um pífano, uma flauta, duas trompas, um clarim com suas competentes voltas e mais caixas de pau para guardar, um zabumba, uma caixa, um par de pratos, tudo muito velho, avaliado em 12 mil réis". ${ }^{81}$ Já a orquestra de Felipe Botelho, outro músico barbeiro - presidente da IBJNR, provavelmente na década de 1830 —, incluía um "baixão", trombas, cornetas, uma delas de chave, zabumbas, além do "fardamento dos músicos".82 Poder-se-ia especular que a uniformização das bandas de música de barbeiro passasse, de algum modo, pela proximidade dos seus donos com os milicianos.

Voltando a Joaquim Cardoso da Costa, na lista de roupas do seu testamento, consta "uma farda de capitão de assaltos". ${ }^{83}$ Efetivamente, em 1790, ele recebera patente de capitão de entradas e assaltos, significando que, junto aos seus negócios de regente de orquestra e da tenda de barbeiro, ocupava o seu tempo em atividades mais virulentas. ${ }^{84}$ Existe, em Vila Rica, nas Minas Gerais, um despacho de 1806, relativo ao "requerimento de Joaquim Cardoso da Costa sobre a licença para utilização de armas por ele e sua tropa". ${ }^{85} \mathrm{~A}$ superposição das atividades de barbeiro, músico e miliciano se repete no nosso próximo irmão.

José Antonio d'Etra era mais um africano jeje, nascido por volta de 1738, pois na hora de seu falecimento, em 7 de maio de 1828, tinha uns 90 anos de idade. ${ }^{86}$ Ele deve ter sido embarcado para as Américas em meados do século XVIII e, na Bahia, foi escravo do capitão de mar Francisco Antonio d'Etra, dedicado ao resgate

\footnotetext{
${ }^{80 " . . . n o v e ~ n a v a l h a s, ~ u m a ~ t e s o u r a, ~ u m ~ p e n t e, ~ d u a s ~ b a c i a s ~ d e ~ l o u c ̧ a, ~ u m a ~ d i t a ~ d e ~ a r a m e, ~ u m ~ p e q u e n o ~ e s p e l h o, ~}$ três toalhas, um banco com sua gaveta, e mais outro dito pela mesma forma, e um velho pequeno": APEB, Judiciário, 04/1724/2194/11, “Inventário e testamento de Joaquim Cardozo da Costa”, 1826, f. 11.

${ }^{81}$ APEB , Judiciário, 04/1724/2194/11, "Inventário e testamento de Joaquim Cardozo da Costa", 1826. Na partilha (f. 10), foram registrados: Albino, moçambique, moço, mestre de música de barbeiro; Quintino e Vitorino, nagôs, moços e tocadores de flauta; Marcos, Benedito e Francisco, moçambiques, tocadores de trompa.

82/dem, Livro de Testamentos n. 30, "Testamento de Felipe Botelho", 1843, ff. 168ss.

${ }^{83} \mathrm{APEB}$, op cit.,

${ }^{84}$ ANTT, RGM/E/105452; Registo Geral de Mercês de D. Maria I, liv. 25, f. 245 v Joaquim Cardoso da Costa, Carta Patente. Capitão de entradas e assaltos da Capitania da Baía. Ca. 18/06/1790. Há um alvará anterior de 1788: APEB, Colonial, maço 375, Livro de Patentes 1788-1789, f. 26.

${ }^{85}$ Arquivo Público Mineiro (APM), Casa dos Contos (CC), cx. 144-21332, Requerimentos/Licenças, 17/03/1806. Há a possibilidade de tratar-se de um homônimo. Porém, ele ainda aparece em Salvador, em 1807 e 1809 , referido como "capitão": ACMS, Freguesia da Conceição da Praia, Livro de Óbitos 1804-1810, f. 314v; Livro de Batismos 1809-1815, f. 278v.

${ }^{86}$ ACMS, Freguesia da Conceição da Praia, Óbitos 1810-1828, f. 314v. Para a identificação da nação jeje (geiges): Freguesia da Conceição da Praia, Livro de Batismos 1826-1834, f. 111v (21 de outubro de 1827).
} 
de cativos na Costa da Mina. ${ }^{87}$ Em 1782, José Antonio aparece pela primeira vez como músico ou regente de orquestra de barbeiros. ${ }^{88}$ Desde 1790 , ele também aparece anualmente nos registros municipais como barbeiro. ${ }^{89}$ Já em 1794, ele recebeu a patente de capitão de entradas e assaltos da freguesia de Paripe. ${ }^{90} \mathrm{Ou}$ seja, o posto de capitão era o último estágio da ascensão profissional.

No início do século XIX, José Antonio morava nas Grades de Ferro, na freguesia da Praia, vizinho à capela do Corpo Santo, onde ficou até morrer. Casou com Mariana Joaquina da Silva Pereira, também jeje e forra, com quem não teve filhos e de quem enviuvou em janeiro de 1811. O casal parece ter vivido em harmonia, pois ela reconhecia o "amor, fidelidade e zelo com que sempre me tratou e boa união que sempre fizemos". ${ }^{91}$ Ele era irmão de pelo menos outras cinco irmandades, indicando seu destaque na comunidade africana da cidade. Em 1801, por exemplo, era consultor da irmandade do Rosário da Baixa de Sapateiros, enquanto sua mulher figura como juíza.$^{92}$ Porém, no registro de óbito, a IBJNR aparece no primeiro lugar, o que talvez indique o grau de preferência que ele sentia por esta. ${ }^{93}$

Já viúvo havia 17 anos, ao redigir o testamento, ele declarava não possuir "ouro nem prata, e menos dinheiro, porque tudo vendi no tempo da guerra para se comer", em referência à guerra da Independência, ocorrida cinco anos antes. Porém, o patrimônio principal de Etra era em escravos, daí a prioridade na alimentação. Em 1806, por exemplo, ele batizava seis cativos de vez. ${ }^{94}$ Anos depois, em 1809, Etra enterrava outros dois: Francisco e Benedito, este um escravo novo (ou recém-chegado), mina, de 16 anos. ${ }^{95}$ No testamento, em 1828, alforriava gratuitamente 15 escravos ( 7 adultos e 8 crias), ordenando alguns deles a ficar na companhia de seus padrinhos. Ele ainda coartou dois escravos e manteve no cativeiro outros quatro (três deles doados a seu herdeiro), perfazendo um total de 21 cativos. Esse não é um número pequeno.

José Antonio d'Etra nomeou como herdeiro e primeiro testamenteiro sua cria (ou seja, nascido na sua casa) Manoel, filho de Antonia d'Etra, provavelmente liberta do mesmo José Antonio, ou do senhor deste, Francisco Antonio. ${ }^{96}$ Como segundo testamenteiro, ele nomeou um seu conterrâneo, o jeje José da

\footnotetext{
${ }^{87}$ Eduardo de Castro e Almeida, "Inventário dos documentos relativos ao Brasil existentes no Arquivo de Marina e Ultramar", Anais da Biblioteca Nacional do Rio de Janeiro, vol. 32, 1910, p.166 (30 de março de 1767, n. 7583). Ele faleceu em 26 de março de 1793: ACMS, Freguesia do Pilar, Livro de Óbitos 1792-1809, f. 8v. ${ }^{88}$ Marieta Alves, "Música de barbeiros", Revista Brasileira de Folclore, vol. 7, n. 17, 1967, p. 11. Também citado por Carvalho Filho como um dos mestres que participava das festas do Senhor do Bonfim: José Eduardo Freire de Carvalho Filho, A devoção do Senhor do Bonfim e sua história, Salvador, Typ. de São Francisco, 1923. ${ }^{89}$ AMS, Livro de Oficinas 1790-1813. Há registros dele até 1810.

${ }^{90}$ ANTT, PT/TT/RGM/E/13024O - Registo Geral de Mercês de D. Maria I, liv. 21, f. 376v. Marieta Alves, op cit., p. 13. ${ }^{91}$ APEB, Livro de Testamentos n. 3, "Testamento de Mariana Joaquina da Silva Pereira”, f. 32. ACMS, Freguesia da Conceição da Praia, Livro de Óbitos 1810-1828, f. 8v.

${ }^{92}$ AINSRBS, Livro 1, f. $204 \mathrm{v}$ e $287 \mathrm{v}$ para a mulher.

${ }^{93} \mathrm{APEB}$, Livro de Testamentos n. 16, “Testamento de José Antônio d’Etra”, f. 100. Além da IBJNR, ele era irmão do Rosário e São Bendito da Conceição da Praia, do Rosário da Baixa de Sapateiros e de São Benedito do convento de São Francisco: ACMS, Freguesia da Conceição da Praia, Livro de Óbitos 1810-1828, f. 314v.

${ }^{94}$ ACMS, Freguesia da Conceição da Praia, Livro de Batismos 1806-09, f. 162v. Entre os padrinhos, estava o jeje Agostinho Maciel, irmão da IBJNR.

95/dem, Freguesia da Conceição da Praia, Livro de Óbitos 1804-1810, f. $310 v$ (24 de junho de 1809) e f. 313 (30 de outubro de 1809).

${ }^{96} \mathrm{Em}$ 1806, Antonia d’Etra aparece como juíza da irmandade do Rosário da Baixa de Sapateiros: AINSRBS Livro 1, f. $71 \mathrm{v}$.
} 
Costa Faria, outro barbeiro, irmão da IBJNR, com tenda na Conceição da Praia. ${ }^{97}$ Aliás, Faria também foi miliciano, recebendo em 1779 a patente de alferes agregado no Terço dos Henriques de Salvador. ${ }^{98} \mathrm{O}$ terceiro testamenteiro foi Geraldo Roiz Pereira, outro influente irmão da IBJNR, com importante participação no tráfico negreiro e com quem José Antonio mantinha relações comerciais.

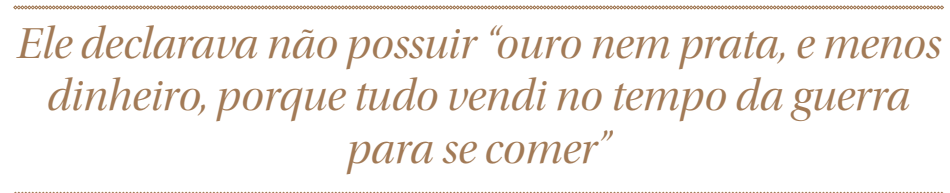

Falarei de Roiz Pereira mais adiante, mas, antes disso, cabe mencionar a notável saga de barbeiros e músicos que se formou na casa d'Etra. O próprio herdeiro, o crioulo Manoel José d'Etra, foi na década de 1840 “dono de uma banda [de barbeiro], na rua das Grades de Ferro: a melhor" ${ }^{\text {"99 }} \mathrm{O}$ jovem Manoel aprendera com seu senhor o ofício de barbeiro e sangrador e de regente de banda de música, mas também se beneficiou dos contatos com os confrades deste, Moraes, Cardoso da Costa, Sampaio e José da Costa Faria. Evidência da estreita relação com Faria, por exemplo, é que Manoel José foi nomeado o seu testamenteiro. ${ }^{100}$

Mesmo ligado à rede social do seu patrono, o crioulo Manoel não aparece como membro da IBJNR, o que pode ser um indício de persistência da exclusividade africana na IBJNR nessa primeira metade do século. ${ }^{101}$ Manoel faleceu em 1856, mas a regência da sua banda de música foi perpetuada por seus libertos. ${ }^{102}$ Todavia, outros cativos de José Antonio d'Etra aprenderam o ofício de barbeiro e sangrador (Figura 4). Por exemplo, em 1808, o

\footnotetext{
97APEB, Judiciário, 04/1711/2181/2, "Inventário de José da Costa Faria”, 1829. Evidência de pertença à IBJNR ACMS, Freguesia da Conceição da Praia, Livro de Óbitos 1828-34, f. 32. No seu testamento, Faria lega, além de bens mais substanciais, 5 pratos de latão para barbas, um estojo com 17 navalhas velhas e enferrujadas e 2 tesouras. José da Costa casou, pouco antes de falecer em agosto de 1829, com a também jeje Maria Rosa da Conceição e eram moradores à rua direita da Misericórdia.

98/dem, Colonial, maço 368, Livro de Patentes n. 29, f. 6.

${ }^{99}$ Almanach para o anno de 1845, Bahia, Typ. de M. A. da S. Serva, 1844, p. 247. Ele morou depois na rua do Sodré. Para mais informações sobre Manoel d’Etra, ver João José Reis, Domingos Pereira Sodré: um sacerdote africano. Escravidão, liberdade e candomblé na Bahia do século XIX, São Paulo, Companhia das Letras, 2008, p. 232; 402. Para sua amizade com Manoel Joaquim Ricardo: João José Reis, "From slave to wealthy African freedman: the story of Manoel Joaquim Ricardo", In: Linda Lindsay; John Sweet (orgs.), Black Atlantic biography, Philadelphia, University of Pennsylvania Press, 2013, p. 131-145.

${ }^{100}$ APEB, Judiciário, 04/1711/2181/2, "Inventário de José da Costa Faria", 1829.

${ }^{101}$ Manoel d'Etra participou de outras irmandades, como a do Rosário da Baixa de Sapateiros, onde foi consultor vários anos entre 1833 e 1851, e a do Rosário da Conceição da Praia, onde foi tesoureiro: AINSRBS, Livro de Irmãos 1850-1876, f. 5; AINSRBS, Livro de Receitas da Irmandade de Nossa Senhora do Rosário da Conceição da Praia 1848-1877, f. 25v.

${ }^{102}$ ACMS, Freguesia de São Pedro, Livro de Óbitos 1855-59, f. 316 (21 de setembro de 1856). Entre 1854 e 1855 , Manoel José aparece como responsável da banda de música. Entre 1857 e 1860, assume Olavo d'Etra e, em 1862, Floripes d'Etra. Entre os barbeiros sangradores, figuram Adão Cyriaco d'Etra (1854-1863), Henrique d'Etra (1857-1858), Olavo José d'Etra (1858), Leocadio Francisco d'Etra (1862-1863) e Floripes d'Etra (18621863): Almanak Administrativo Mercantil, e Industrial da Bahia, 1854-1863. Enquanto Adão foi, provavelmente, escravo de Ciriaco José d'Etra (um dos libertos de José Antonio), Olavo, Floripes e Leocadio foram, provavelmente, escravos de Manoel José.
} 


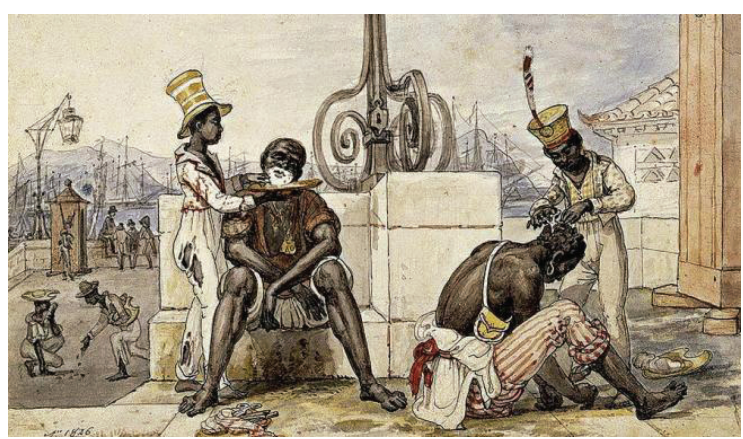

Figura 4. Barbeiros ambulantes, 1826 - Rio de Janeiro. Aquarela de Jean Baptiste Debret.

jeje Maximiano d'Etra recebia uma licença para sangrar e lançar ventosas. ${ }^{103}$ O também jeje Francisco Nazaré d'Etra, que se casou com Julia Soares, a primeira ialorixá do terreiro Gantois, aparece como barbeiro em $1845 .{ }^{104} \mathrm{O}$ nagô Atanásio, que foi réu na Revolta dos Malês, em 1835, viajou nesse ano para a Costa da África com o também nagô José Bernardino da Costa Faria. Escravo do já citado José da Costa Faria, Bernardino foi um importante barbeiro, sangrador e criador de sanguessugas, com alianças também com o mundo do Candomblé. ${ }^{105}$ Aliás, ele viria a ser escrivão da IBJNR em 1853. ${ }^{106}$ Outro escravo de José Antonio, o nagô Ciriaco, também barbeiro, solicitou passaporte para a África em 1844 e em 1847. ${ }^{107}$

O envolvimento, direto ou indireto, no tráfico de alguns dos irmãos da IBJNR, como José Antonio d'Etra, permite supor que alguns de seus aprendizes de barbeiro trabalhavam nos navios negreiros, oferecendo atendimento médico rudimentar aos cativos e participando do negócio em pequena escala, quando a oportunidade o permitia. ${ }^{108} \mathrm{O}$ mina Antonio Mendes dos Santos, por exemplo, irmão da IBJNR, andava desde 1807 "embarcado para a Costa da África e Europa, como barbeiro". Ele teve um escravo, Joaquim, também barbeiro sangrador. ${ }^{109}$ Francisco Nazaré (distinto daquele da casa d'Etra) tam-

\footnotetext{
${ }^{103}$ Marieta Alves, "Música de barbeiros", Revista Brasileira de Folclore, vol. 7, n. 17, 1967, p. 12; cf. AMS, Livro de Cartas de Exame de Officiaes, 1770-1809 - a licença é de 27 de outubro de 1808.

${ }^{104}$ Edição fac-similar do Almanach Civil, Politico e Commercial da Cidade da Bahia para o Anno de 1845: Typ. de Manoel Antonio da Silva Serva, Salvador, Fundação Cultural do Estado da Bahia, 1998, p. 246.

${ }^{105}$ APEB, Colonial, maço 2.949, Presidência da Província chefes de Policia 1835-1841. Em 30 de outubro de 1835, Atanásio solicita passaporte para a Angola e José Bernardino da Costa Faria, para "Havana e Angola por escalas pela África": Idem, Colonial, Livro de Passaportes n. 5.883, f. 118. Bernardino teve trânsito nos candomblés da Casa Branca e do Gantois.

106/dem, Colonial, maço 5.266, f. 62. Publicado em "Tombo dos bens das Ordens Terceiras, Confrarias e Irmandades da Cidade do Salvador em 1853", Publicações do Arquivo do Estado da Bahia, vol. 7, Salvador, Imprensa Oficial, 1948, p. 89.

107/dem, Livros de Passaportes n. 5.886, f. 314; n. 5.888, f. 374.

${ }^{108}$ Maria Cristina Wissenbach, "Cirurgiões e mercadores nas dinâmicas do comércio atlântico de escravos", In: Laura de Mello e Souza; Junia Ferreira Furtado; Maria Fernanda Bicalho (orgs.), O governo dos povos, São Paulo, Alameda, 2009, p. 281-300; Jacimara Souza Santana; Andreilza Oliveira dos Santos, "Sangradores africanos na Bahia do Século XIX (1825-1828)", Sankofa, vol. 3, n. 6, 2010, p. 56.

${ }^{109}$ APEB, Livro de Testamentos n. 30, "Testamento de Antonio Mendes dos Santos", 1843, f. 32v. A solicitação de passaporte para a Africa, em 1842: APEBA, Colonial, maço 6.349, Fundo Polícia, 1821-42. O escravo Joaquim aparece sob a categoria de barbeiro-sangrador entre os anos de 1854 e 1863: Almanak Administrativo Mercantil, e Industrial da Bahia.
} 
bém viajou, em 1828, "de barbeiro para os portos da África”, levando uma carregação de "diferentes miudezas próprias do negócio da Costa". Ele deixou seu escravo Manoel, um moleque nagô, aprendendo "o ofício de barbeiro na tenda de Antonio de Araujo Santana", outro barbeiro mina, próximo do círculo social da IBJNR, bem conhecido pelo seu envolvimento no tráfico atlântico. ${ }^{110}$

Sumariando, o ofício de barbeiro, com seus desdobramentos terapêuticos e lúdico-musicais, era uma atividade privilegiada na IBJNR. A relação entre senhor e escravo convertia-se, amiúde, numa relação de mestre-aprendiz, sendo o ofício transmitido de geração a geração desde o século XVIII até pelo menos a década de 1860. A profusão de barbeiros na irmandade, como foi dito, parece lhe conferir um caráter de corporação profissional. Por outro lado, o envolvimento de vários desses barbeiros africanos com o tráfico emerge como um aspecto notável que abre essa orientação profissional para âmbitos mercantis mais amplos. ${ }^{111}$

\section{Comerciantes, traficantes e a lógica da inserção e ascensão social}

O corporativismo dos músicos-barbeiros-sangradores emerge como um fenômeno quase exclusivamente africano, ou pelo menos circunscrito à população negra. No entanto, a ascensão social dos libertos da IBJNR passava também por uma relativa inserção no mundo dos ex-senhores, fossem eles brancos ou africanos. A manutenção de relações duradouras, de tipo afetivo ou por interesse compartilhado, entre libertos e ex-senhores era frequente. Vários deles, nos seus testamentos, pedem missas pelas almas de seus patronos ou expressam seu agradecimento pela educação recebida. ${ }^{112}$ Mas essas relações iam além da esfera afetiva e educacional e podiam envolver, como vimos, parcerias profissionais e comerciais. O termo "patrono" conota a figura do pai, mas tem igualmente o sentido de protetor. Protegidos e inseridos no círculo social dos seus patronos, esses "libertos dependentes" combinavam formas de sujeição ideológica e paternalismo. ${ }^{113}$

\footnotetext{
10APEB, Judiciário, 5/2011/2982/4, “Inventário de Francisco de Nazaré”, 1832.

"'A superposição das funções de barbeiro, regente de banda de música e capitão não era exclusiva dos africanos da IBJNR. Ver, por exemplo, o caso do crioulo Joaquim Felix de Santana, capitão dos Henriques, barbeiro e dono de orquestra: APEB, Livro de Testamentos n. 7, "Testamento de Joaquim Felix de Santana", 1814, ff. 30-42. Ver também: Kátia Mattoso, "Testamentos de escravos libertos na Bahia no século XIX: uma fonte para o estudo das mentalidades", In: ___ Da revolução dos Alfaiates à riqueza dos baianos no século XIX: itinerário de uma historiadora, Salvador, Corrupio, 2004 [1979], p. 250 et seq.

${ }^{112}$ Ver, por exemplo, "Testamento de José da Penha Ferreira", 1810, em APEB, Judiciário, Processo Cível 87/3099/16, "Irmandade Bom Jesus das Necessidades e Redenção contra Agostinha Romana de Vargas", 1846-1850, ff. 67ss; Judiciário, Livro de Testamentos n. 19, "Testamento de Rita Rosa de São José”, 1830, f. 244250; Livro de Testamentos n. 4, "Testamento de Joam Gomes Touquinho", 1814, f. 180; Livro de Testamentos n. 11, "Testamento de Ignácio Sampaio", 1823, ff. 199-202; Livro de Testamentos n. 3, "Testamento de Francisco Nunes Morais", 1811", ff. 34v, 37-38.

${ }^{113}$ Manuela Carneiro da Cunha, Negros estrangeiros: os escravos libertos e sua volta à África, São Paulo, Brasiliense, 1985, p. 100. Para o tema do paternalismo nas relações entre senhores e escravos, ver, entre outros, Sidney Chalhoub, Visões da liberdade: uma história das ultimas décadas da escravidão na Corte, São Paulo, Companhia das Letras, 1990. Sobre mobilidade social, ver, por exemplo, Robert W. Slenes, "A 'Great Arch' descending: manumission rates, subaltern social mobility and the identities of enslaved, freeborn and freed blacks in Southeastern Brazil, 1791-1888", In: John Gledhill; Patience Schell (orgs.), Rethinking histories of resistance in Brazil and Mexico, Durham, Duke University Press, 2012, p. 103-109.
} 
Óbvio que as relações entre libertos e ex-senhores não eram sempre benévolas, nem isentas de tensões e conflitos. Porém, cabe cogitar sobre a possível correlação entre os processos de cooperação e acomodação aos padrões dos patronos e a prosperidade de alguns desses libertos. O casamento na igreja era um desses "padrões" e não é descabido pensar que a ascensão social e o acúmulo de riqueza dos africanos fossem reforçados, de algum modo, pela aliança matrimonial e, em alguns casos, pela ausência de descendência. Aliás, várias das consortes desses libertos eram irmãs da IBJNR, indicando a superposição das redes de afinidade matrimonial e parentesco espiritual. ${ }^{114} \mathrm{~A}$ adesão à fé católica, por sua vez, pode ser interpretada como outro mecanismo de inserção na sociedade colonial, não necessariamente envolvendo uma "conversão" que repudiava o universo religioso africano, mas uma adoção de um código e de uma imagem pública percebidos como requisito imprescindível para participar das redes sociais e comerciais que possibilitavam a almejada ascensão social. ${ }^{115}$

Não estou postulando que a chave do sucesso fosse a assimilação. Como aponta Maria Inês Cortes de Oliveira, "os africanos utilizavam a linguagem da cultura dominante para adquirirem o direito de expressar seus interesses".116 Talvez possamos falar de um processo de ladinização, no sentido de uma tentativa de apropriar-se dos códigos e comportamentos do senhor - não apenas culturais, mas também mercantis - para melhor controlá-los e tirar deles partido em beneficio próprio. ${ }^{117}$ Ora, como espero ter deixado claro, ao lado da interação com os "patronos", parte importante do sucesso social desses libertos devia-se à sua paralela articulação com seus pares africanos, principalmente nas irmandades, associações que, à primeira vista, aparecem como espaços de acomodação.

Essa dupla dinâmica de adaptação estratégica ao meio senhorial e cooperação intra-africana pode ser ilustrada com o terceiro testamenteiro de João Nunes na Bahia e também vizinho na Saúde, o africano José Gomes da Conceição. No seu testamento, ele se declarava "natural da Costa de Leste" e, num documento do inventário, sua mulher o identifica como da Costa da Mina. ${ }^{118}$ Assim, poder-se-ia tratar da parte leste da Costa da Mina, ou seja, dos ditos "portos de baixo", como Porto Novo, Apa ou Badagry. Se, alternativamente, ele fosse moçambique, seria exceção notável num círculo predominantemente jeje. Ele ocupou o cargo de tesoureiro na IBJNR e, em 1813, ano em

\footnotetext{
${ }^{114} \mathrm{~A}$ entrada conjunta de cônjuges nas irmandades já tinha sido notada em outras irmandades: Socorro Targino Martínez, Ordens terceiras: ideologia e arquitetura, Dissertação de mestrado, Universidade Federal da Bahia, Salvador, 1979, p. 82ss; 128: apud Lucilene Reginaldo, Os Rosários dos Angolas: irmandades de africanos e crioulos na Bahia setecentista, São Paulo, Alameda; Fapesb, 2011, p. 58.

${ }^{15}$ Não cabe no limite deste texto aprofundar nos processos de "sincretismo" ou justaposição entre práticas religiosas africanas e devoção católica, fenômeno que era frequente no seio da IBJNR.

${ }^{16}$ Maria Inês Cortes de Oliveira, O liberto: o seu mundo e os outros (Salvador, 1790-1890), Salvador, Corrupio, 1988, p. 74.

${ }^{117}$ Para uma interpretação do conceito de ladinização, ver João José Reis, Domingos Pereira Sodré: um sacerdote africano. Escravidão, liberdade e candomblé na Bahia do século XIX. São Paulo, Companhia das Letras, 2008, p. 316-317.

${ }^{118}$ APEB, Judiciário, O4/1511/1980/O1, “Inventário de José Gomes da Conceição”, 1813, f. 17.
} 
que faleceu, foi consultor. A primeira testamenteira e herdeira foi sua mulher, Mariana Angélica do Coração de Jesus, de nação angola, com quem teve duas filhas (Maria do Nascimento e Maria Angélica). O terceiro testamenteiro foi João Gomes Touquinho, o mesmo que se ocupara da testamentaria de Nunes e também o seu vizinho. ${ }^{119}$

José Gomes foi batizado na Conceição da Praia, "sendo escravo de Luiz de Souza Gomes, então solteiro, o qual me conferiu a liberdade, dando eu outro escravo em meu lugar". Esse tipo de arranjo, incomum mas possível, já sinaliza uma relação privilegiada com seu senhor. ${ }^{120}$ Ele teria aprendido o ofício de sapateiro enquanto escravo, pois, como liberto, com a ajuda do seu patrono que lhe alugava uma loja na rua dos Algibebes, na cidade baixa, ele se dedicou ao comércio de couros e molhados, sobretudo sapatos de homem, chinelos de mulher, cordavões, cadarços, formas de sapateiro, meias, fio de capa, mas também azeite de peixe, soja, fazendas etc. Em 1811, já liberto, ele aparece como "sapateiro" nos registros municipais. ${ }^{121}$

No ano do seu falecimento, ele era senhor de cinco escravos, dois moços angolas e três mulheres jejes. Gomes possuía também três casas de moradia, uma térrea na rua das Flores e duas de "dois sobrados" na rua direita do Fortinho e na rua direita da Saúde. A última, onde morava, comprada por 200 mil réis em 1804, quando era apenas "uma morada de casas de taipa com seu quintal", foi avaliada em 1 conto e 200 mil réis em 1813, quando ainda estava em construção. ${ }^{122}$

José Gomes cultivou habilidosamente sua relação de "dependência" com seu patrono, e com os parentes dele, para negociar sucessivos créditos e, a partir desse capital, revalorizar seus investimentos em imóveis e mercadorias. Assim, embora sem ativo, ele acumulou um monte-mor de quase quatro contos e meio de réis, mas a aparente riqueza não correspondia ao patrimônio real e a viúva enfrentou problemas para pagar as dívidas que foram surgindo após a sua morte. ${ }^{123}$ Seja como for, em vida, o africano José Gomes da Conceição viveu como um próspero comerciante, com loja na vibrante cidade baixa e ostentando um luxo que certamente causava admiração.

A ascensão social do liberto lhe permitiu garantir um futuro promissor à sua descendência crioula. Em 21 de junho de 1814, a filha mais velha, Maria Angélica do Coração de Jesus, com 19 anos, pedia licença para casar com o ajudante de entradas e assaltos da freguesia da Conceição da Praia, Geraldo Roiz Pereira, "homem preto com procedimento que a suplicante [a mãe] tem

\footnotetext{
${ }^{119}$ APEB, Judiciário, 04/1511/1980/01, “Inventário de José Gomes da Conceição”, 1813. O testamento foi redigido em 24 de março de 1813. João José Reis, em A morte é uma festa, São Paulo, Companhia das Letras, 1991, p. 152, identifica outro africano - José Gomes da Conceição, falecido em 1827.

${ }^{120}$ João Reis está presentemente desenvolvendo uma pesquisa sobre escravos proprietários de escravos na Bahia. ${ }^{121}$ AMS, Livro de Oficinas 1790-1813, f. 150.

122Para a compra: APEB, Judiciário, Livro de Notas n. 148, f. 126. A viúva, Mariana Angélica do Coração de Jesus, acabou vendendo a casa na Saúde por 570 mil réis, em 22 de maio de 1822: APEB, Judiciário, Livro de Notas n. 207, f. 197.

${ }^{123} \mathrm{APEB}$, op cit., ff. 41ss.
} 
indagado, que faz o bem da dita sua filha". ${ }^{24}$ O posto de ajudante de capitão do mato, na freguesia onde desembarcava a maioria dos escravizados, envolvia um contato cotidiano com os capitães de navio e os donos dos entrepostos onde eram mantidos os cativos até sua venda e teria favorecido o posterior envolvimento de Geraldo no tráfico, levando-o a ficar muito mais rico do que seu sogro. Como vimos, Roiz Pereira foi testamenteiro de José Antonio d'Etra e, como este, também estava afiliado à IBJNR. Constata-se, assim, como a irmandade foi recrutando sucessivas gerações de africanos, tecendo no seu seio alianças étnicas, espirituais, de parentesco e comerciais que reforçaram a articulação de uma elite negra na Bahia. A figura de Roiz Pereira e sua rede social trazem de volta a hipótese de uma relação entre a afiliação à irmandade e as atividades mercantis associadas ao tráfico.

Geraldo era natural da Costa da Mina e, por um tempo não determinado, foi escravo do influente João Ferreira de Bittencourt Sá. ${ }^{125}$ Geraldo faleceu em 15 de março de 1830 e foi enterrado com grande pompa, com mestre de cerimônias, 27 padres e música de órgão, na matriz da freguesia do Pilar, onde morava. ${ }^{126}$ Sem filhos do casamento, nomeou herdeira a menor Joana Maria do Coração de Jesus, ex-escrava do seu padrinho, Manoel Pereira Lopes. Como seu confrade d'Etra, Geraldo pertencia a várias irmandades, mas nos seus legados a estas, a primeira nomeada foi a IBJNR, tendo recebido também a maior quantidade, 25 mil réis, o que sinaliza a hierarquia da sua preferência. ${ }^{127}$

No testamento, Geraldo lista 15 escravos da sua propriedade, quatro mulheres e 11 homens (um mina, um haussá, um cabinda, um jeje e sete nagôs). Oito deles deixava forros e dois, coartados. Contudo, no inventário (um documento com mais de 200 fólios), aparecem mais seis moleques novos, todos marcados ao ferro. Aliás, o primeiro testamenteiro e inventariante, o capitão João Pereira de Araujo e França, também notório traficante, declarou "haverem mais 15 escravos novos, em que o casal tem sociedade com Inocêncio de Araujo Santana", somando um total de 36 cativos. ${ }^{128}$ Essas partidas de escravos recém-chegados são prova inquestionável do envolvimento de Geraldo no tráfico clandestino, pois ele lucrou com resgate de cativos na Costa da Mina, na década de 1820, quando o comércio estava proibido ao norte da linha do Equador.

\footnotetext{
${ }^{124}$ APEB, Judiciário, 04/1511/1980/01, “Inventário de José Gomes da Conceição”, 1813, f. 17. Geraldo Roiz Pereira casou em julho de 1814: ACMS, Freguesia de Santana, Livro de Casamentos 1783-1818, f. 196v. Ele recebeu a patente de ajudante de entradas em 1809: APEB, Colonial, maço 390, ff. 68-69.

${ }^{125}$ Entre 1755 e 1766, João Ferreira Bittencourt foi sucessivamente juiz de fora da cidade da Bahia, escrivão dos sequestros dos bens dos jesuítas, intendente e primeiro ministro da mesa da inspeção da Bahia e desembargador intendente geral do ouro: AHU_ACL_CU_O05, Cx. 123, d. 9606; Cx. 152, d. 11639, Cx. 157, d. 11945 e 11958; Inácio Accioli, Memórias históricas e políticas da província da Bahia, vol. 5, Salvador, Imprensa Oficial, 1940, p. 588.

${ }^{126}$ ACMS, Freguesia do Pilar, Livro de Óbitos 1824-1834, f. 39. O organista foi Ignácio Manoel Porcinicula, o seu segundo testamenteiro: APEB, Judiciário, O3/1094/1563/03, "Inventário de Geraldo Rodrigues Pereira", 1830, ff. 35, 38.

${ }^{127}$ APEB, Livro de Testamentos n. 19, "Testamento de Geraldo Rodrigues Pereira", 1830, ff. 257-63. Ele foi irmão das irmandades Nossa Senhora da Conceição da Praia, do Rosário da Praia e do Rosário da Baixa de Sapateiros. Para a última: AINSRBS, cx. 10, doc. 9, Livro de Irmãos, s/d, f. 34v.

${ }^{128}$ APEB, Judiciário, 03/1094/1563/03, "Inventário de Geraldo Rodrigues Pereira”, 1830, ff. 44, 136v, 138, 154, 178 e 191. O testamenteiro França aparece como proprietário de vários navios negreiros, com viagens entre 1805 e 1828, todas ao golfo do Benim: TSTD, n. 51.442, 51.455, 49.454, 51.472.
} 
Esse negócio explica a prosperidade do africano que acumulou um monte-mor superior a 33 contos de réis, compreendendo cinco casas, uma delas de dois andares, na freguesia do Pilar, onde morava, mobiliada com objetos luxuosos, como 12 quadros de molduras douradas. Dentre seus objetos pessoais, aparecem instrumentos que delatam sua atividade comercial, como "ferramentas de ferreiro" (para fabricar grilhões?), um "óculo de ver ao longe", "um par de pistolas" e "um cofre de ferro com chave de segredo". ${ }^{129}$

Geraldo emprestava avultadas somas de dinheiro, mas também incorria em dívidas importantes. Entre os parceiros comerciais, podemos destacar o seu já citado sócio, o africano jeje Inocêncio de Araujo Santana. O mina Antonio de Araújo Santana - o já referido barbeiro, talvez ex-escravo de Inocêncio declarava ter remetido da Costa da África vários escravos consignados a Geraldo (provavelmente aquela partida de 15 moleques novos). Consta uma escritura e uma letra no valor de 364 mil réis a Francisco da Silva Guerra, o acompanhante de João Nunes na sua viagem a Benguela. Figura ainda uma dívida de 260 mil réis com Joaquim d'Almeida, outro jeje que mantinha estreitos laços com a IBJNR e se tornaria importante traficante também. Entre os credores, figuram o barão de Itaparica e outras companhias comerciais. Geraldo complementava suas carregações de cativos com outras mercadorias, como panos da costa, peles de onça e azeite de dendê. ${ }^{130} \mathrm{Um}$ dos seus fornecedores em Onim (Lagos), por exemplo, Francisco Simões, reclamava à viúva uma dívida pelo envio de uma quartela e um barril de azeite de dendê em $1829 .{ }^{131}$

\section{O africano José Gomes da Conceição viveu como um próspero comerciante, com loja na vibrante cidade baixa e ostentando um luxo que certamente causava admiração}

Geraldo também viajava. Em janeiro de 1826, ele solicitou passaporte para a Costa d'África, levando em sua companhia quatro crias: Bento, Germano, José e João. ${ }^{132}$ Destes, o jovem Bento, de nação mina, foi enviado para a Costa d'África de novo em outubro 1829, pouco antes de Geraldo falecer. ${ }^{133}$ Bento foi alforriado e recebeu uma esmola de 100 mil réis por verba testamentária. No inventário, figuram ainda 40 mil réis pagos "ao escravo Bento de sua passagem", talvez a de 1829. ${ }^{134}$ Em 1831, Bento comprou uma das escravas novas trazidas pelo defunto senhor. ${ }^{135}$ Esses indícios sugerem a participação de Bento no tráfico, reiterando o padrão de envolvimento e aprendizado dos cativos nas

\footnotetext{
129APEB, Judiciário, 03/1094/1563/03, "Inventário de Geraldo Rodrigues Pereira”, 1830, f. 16v, 17, 18v.

130/bidem, ff. 29, 33v, 43-44, 88.

131/dem, Judiciário, Libelo Cível, 16/0541/06 “Francisco Simões contra Maria Angélica Coração de Jesus”, 1831.

132/dem, Colonial, Livro de Passaportes n. 5.878, f. 155 (21 de janeiro de 1826).

133/dem, Colonial, Livro de Passaportes n. 5.879, f. 161 (10 de outubro de 1829).

134/dem, Judiciário, 03/1094/1563/03, "Inventário de Geraldo Rodrigues Pereira”, 1830, f. 32v.

135/bidem, f. 179.
} 
atividades profissionais dos seus patronos. Ou seja, não eram apenas ofícios como o de barbeiro que eram ensinados, mas também habilidades comerciais no recrutamento, compra, custódia e embarque de cativos.

Em 1835, Bento Roiz Pereira voltou para a Costa d'África, levando sua mulher, dois filhos menores, duas escravas e uma cria, instalando-se em Agoué, aldeia que se converteria, a partir de então, num dos portos mais importantes do tráfico ilegal na Costa da Mina. ${ }^{136}$ Outro retornado da Bahia que lá se instalou foi o africano mahi Joaquim d'Almeida, já mencionado. Além de se tornar o traficante mais renomado desse porto, ele é lembrado por ter levantado em Agoué, provavelmente na década de 1840, uma capela sob a invocação de Nosso Senhor da Redenção. Mais uma vez, a rede do tráfico associada à IBJNR se estendia, como nos tempos de João Nunes, para o outro lado do Atlântico. ${ }^{137}$

Desde as viagens a Luanda e Benguela do final do século XVIII até o fim do período do tráfico ilegal, em meados do século XIX, a IBJNR parece ter fornecido uma rede de apoio a alguns dos seus membros nas atividades do nefando comércio. Se irmãos como João Nunes ou Guerra podem ter participado em pequena escala e outros, como José Antonio d'Etra, podem ter se beneficiado apenas de forma indireta, como receptores ou compradores, houve ainda outros, como Geraldo Roiz Pereira, Inocêncio de Araujo Santana, Antonio de Araujo Santana ou Joaquim d'Almeida, que investiram mais pesado e intensificaram o volume dessa atividade mercantil. Nesse último nível, obviamente, a rede comercial excedia o círculo dos africanos da irmandade e se inseria num circuito socioeconômico maior, que atravessava barreiras de etnia, cor e nacionalidade. Contudo, a perpetuação desses interesses comerciais no seio da irmandade, ao longo das gerações, confere à congregação um caráter típico dos grupos corporativos.

\section{A irmandade como potencial associação mercantil}

Lucilene Reginaldo considera que as confrarias católicas e as corporações militares aglutinaram "a elite" dos homens de cor na América Portuguesa. ${ }^{138}$ A notória presença de milicianos na IBJNR sugere que os membros dessa elite coparticipavam das duas instituições. Além dos capitães do mato e dos Henriques, a presença de comerciantes, barbeiros, regentes de bandas de músicos, marinheiros e traficantes de escravos confirma a assertiva de a IBJNR ter agregado em seu seio, entre 1770 e 1830, o setor relativamente mais bem sucedido da comunidade africana de Salvador. Essa elite era, naquela virada de século, predominantemente mina e jeje, mas assentou as bases para o desenvolvimento, a partir dos anos 1820, de uma elite majoritariamente nagô. Eu me atreveria a dizer que a irmandade reunia um grupo restrito de africanos que, pela sua inserção no mercado capitalista e pela sua capacidade para acumular riqueza,

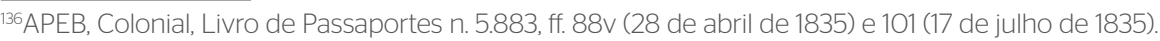

${ }^{137}$ Sobre Joaquim d'Almeida, ver Pierre Verger, Os libertos: sete caminhos na liberdade de escravos da Bahia no século XIX, Salvador, Corrupio, 1992, p. 42-48; 116-121.

138Lucilene Reginaldo, Os Rosários dos Angolas: irmandades de africanos e crioulos na Bahia setecentista, São Paulo, Alameda; Fapesb, 2011, p. 345.
} 
sobretudo na forma de escravizados e imóveis, poderia ser caracterizada como o "embrião" de uma pequena "burguesia" negra. Mesmo que de forma precária e instável e sempre sujeita à exclusão política, essa comunidade afro-baiana mais próspera se perpetuou até pelo menos a chegada da República.

Diante das representações das irmandades de homens pretos como agremiações preocupadas com a assistência aos enfermos, a organização das exéquias e a alforria de seus membros, a IBJNR aparece como uma sociedade, efetivamente de ajuda mútua, mas orientada, sobretudo, a satisfazer os interesses dos mais poderosos. A conversão à devoção católica dos africanos tem sido interpretada como exemplo de abrasileiramento cultural e, como foi apontado, a adoção dos modos das elites brancas pode ter sido uma forma de conseguir uma mobilidade social mais rápida. Mas a conversão não se limitava à espiritualidade ou à cultura e dizia respeito, especialmente, à réplica de um modus operandi de ordem econômica, à inserção na dinâmica do mercado e do trabalho e, quando possível, na sua máxima expressão na época, que era o tráfico de escravos.

Em termos morais, a adesão ao cristianismo dos libertos não impunha, aparentemente, qualquer tipo de remorso ou constrição em relação ao seu envolvimento no infame comércio, ao contrário, a conversão parece ter funcionado como um pré-requisito, uma marca de prestígio que legitimava o envolvimento numa economia diferenciada. Assim, as maneiras católicas podiam favorecer aos africanos na sua interlocução e negociação com capitães de navio, armadores ou sócios capitalistas, brancos e pardos, brasileiros ou portugueses. O catolicismo, nesse sentido, pode ser interpretado como condição necessária para a inserção numa comunidade mercantil.

Tentei sugerir uma compreensão da irmandade além do religioso, como uma sociedade capitalista "em potencial". Lembro que no termo que acompanhava o compromisso original, datado em 13 de abril de 1776, os irmãos se obrigavam a prestar contas à Provedoria dos Resíduos e Capelas e a não reeleger tesoureiro, nem "darem dinheiros a juros".139 A imposição desse termo sugere que a agiotagem, ou a especulação com o fluxo financeiro, era uma das dinâmicas que as autoridades pretendiam controlar. Nas contas das irmandades, poucas vezes emergem despesas fora dos custos das festas e dos enterros, mas desconfio que pudesse existir o que hoje chamaríamos de um "caixa 2" que permitisse capitalizar outros investimentos.

Na década de 1830, há evidência de avultados empréstimos que a irmandade fazia a alguns dos seus membros, como os 600 mil réis passados ao traficante Luiz de Campo Souza, que fora presidente e membro da mesa diretora nesse período. ${ }^{140}$ Porém, a irmandade também contraia dívidas consideráveis. Por exemplo, em 25 de novembro de 1830, o procurador da IBJNR, João Barboza de Oliveira, registrou uma escritura de débito, obrigação e hipoteca que a irmandade fez em favor de outro dos seus irmãos, José Marques de Oliveira, um jeje

\footnotetext{
${ }^{139}$ ACMS, Est. 1; Cx. 32; Cx. Arq. 162-As1; doc. 38: "Bom Jesus das Necessidades e Redempção", Lisboa, Oficina de Antonio Rodrigues Galhardo, Impressor da Real Meza Censoria, 1778.

${ }^{140}$ APEB, Livro de Testamentos n. 28, "Testamento de Luis de Campos Souza”, 1841, f. 189ss.
} 
também associado ao tráfico clandestino. Este tinha saldado uma dívida de 397 mil réis que a mesa da irmandade contraíra com João Pinto de Cerqueira, para evitar uma execução judicial de embargo. Como bom negociante que era, José Marques de Oliveira ia cobrar juros pelo empréstimo. ${ }^{141}$

Ou seja, além de suporte no além, a irmandade oferecia apoio em assuntos deste mundo e não se limitava ao comércio, mas também podia envolver processos judiciais e prestação de contas. Por exemplo, quando em 1810 Touquinho apresentou ao juiz de fora e órfãos as despesas relativas à tutoria das herdeiras de João Nunes, 2 das 3 testemunhas que referendaram as contas eram irmãos da IBJNR: Guerra e Ignácio de Sampaio. Ou seja, a irmandade oferecia uma rede social e logística que atendia às demandas legais de seus membros.

Outra área de investimento das irmandades era o patrimônio imobiliário. Na IBJNR, há indícios de uma primeira doação na década de 1810, no testamento do capitão José da Penha Ferreira já referido. Ele deixou suas duas casas, uma na Baixa de São Bento e a outra na Ladeira das Hortas, à sua mulher, a mina Clara Alvares Ferreira, e a três escravos alforriados do casal. Contudo, Penha especificava que, por morte dela e de seus libertos, as casas deviam ser legadas à IBJNR. Com os rendimentos dos aluguéis, ele pedia missas semanais pela sua alma e pelas almas da sua mulher, da sua mãe e de sua ex-senhora. Penha faleceu em 1823; porém, a irmandade só reclamou o legado desses imóveis em 1846, quando já tinham sido vendidos. ${ }^{142}$ Talvez não tenha sido por acaso que a IBJNR veio a preocupar-se com esse patrimônio no momento em que as possibilidades do tráfico começavam a se esgotar. Em 1853, a IBJNR tinha três casas, mas a irmandade do Rosário da Baixa de Sapateiros, para citar a mais rica entre aquelas de africanos, possuía 13 casas e 5 terrenos na cidade. ${ }^{143}$ Essa economia imobiliária que funcionava por trás das atividades religiosas cresceu até a década de 1860, conferindo a essas sociedades assistenciais uma dimensão patrimonial e corporativista.

Obviamente, não pretendo reduzir a IBJNR a um mero grupo de traficantes e especuladores imobiliários, mas sim apontar para a política econômica subjacente às relações de poder e clientelismo que teciam a sociabilidade da instituição. Para além de um mero cenário de promoção social e de expressão da identidade cultural das elites negras, as irmandades podiam funcionar como redes facilitadoras de alianças e cooperação intraétnica, comparáveis aos grupos de interesse, ou lobbies, que atuam no competitivo e dinâmico sistema

\footnotetext{
$\overline{{ }^{14} A}$ APEB, Livro de Notas n. 236, f. 139. O envolvimento de José Marques de Oliveira com o tráfico é sugerido por suas relações de compadrio com José Antonio d’Etra e Luis Xavier de Jesus. O último, bem conhecido por suas atividades no tráfico, apadrinhou uma das filhas de Marques: ACMS, Freguesia da Conceição da Praia, Livro de Batismos 1809-1815, ff. 364v (19 de março de 1814) e 370v (30 de maio de 1814). Esse negócio explicaria a afluência que lhe permitiu assumir a dívida da IBJNR.

142/dem, Judiciário, Processo Cível 87/3099/16, "Irmandade Bom Jesus das Necessidades e Redenção contra Agostinha Romana de Vargas", 1846-1850, ff. 70v-71. A verba relativa à cessão das casas está também transcrita em: BICP, papéis avulsos, 1860. Para outro caso parecido: Idem, Livro de Testamentos n. 22. “Testamento de Jacinta de Araujo Ribeiro", 1830, f. 256v; Livro de Testamentos n. 28, "Testamento de Luis de Campos Souza”, 1841, f. 190.

143/dem, Colonial, maço 5.266, "Livro do Tombo dos bens de todas as Ordens Terceiras, Confrarias e Irmandades da Cidade do Salvador em 1853", ff. 62, 69-71v. Para outro caso de cessão de imóveis às irmandades, ver: Idem, Judiciário, Livro de Testamentos n. 6, “Testamento de Joaquim Nunes de Gouvea”, 1816, f. 194.
} 
capitalista. As irmandades podem ser caracterizadas, assim, como espaços de solidariedade ao serviço de interesses coletivos africanos e, nesse sentido, cabe falar de uma apropriação ou africanização da instituição.

Diante da aparente democratização das irmandades de Nossa Senhora do Rosário, aceitando membros de diversos status legais e condições econômicas, o ethos da IBJNR, com alta densidade de capitães e senhores de escravos, parece ter preservado, ressalvando as distâncias, o caráter mais fechado e aristocrático das velhas irmandades ibéricas. ${ }^{144}$ Nestas, "o estatuto social e profissional constituía um critério determinante" e, quem sabe, no Corpo Santo não se preservasse certa dinâmica seletiva, pelo menos na esfera da mesa diretora, em virtude das afinidades étnicas e das atividades profissionais e comerciais de seus membros. ${ }^{145}$

Em definitivo, como já avisara Roger Bastide, sob formas de aparente aculturação, escondiam-se formas de contra-aculturação. ${ }^{146}$ Utilizando termos mais atuais, poderíamos dizer que as irmandades de homens pretos constituíam um espaço simultâneo de ladinização e de africanização. Havia assimilação no sentido de replicar um modelo preexistente associado ao catolicismo dominante, mas essa acomodação era também apropriação estratégica que abria espaço para concorrer na dinâmica do mercado e para poder encenar, na esfera pública, o teatro social e político que podia promover oportunidades aos africanos. Sob essa perspectiva, as irmandades apresentavam características parecidas com as dos cabildos de nación em Cuba, apontando para a reprodução, em várias partes do Atlântico, de expressões culturais e dinâmicas econômicas semelhantes, porém resultado de processos sociais independentes. ${ }^{147}$

\footnotetext{
144Sobre o caráter "democrático" das irmandades do Rosário: Lucilene Reginaldo, "Travessias, trânsitos e conexões de Lepanto à Kalunga: irmandades e devoções negras em Portugal, na América portuguesa e em Angola no século XVIII", texto apresentado na conferência Africanos nas Américas: reconstruindo vidas num Novo Mundo, 1675-1825, University of the West Indies, Barbados, 14 a 16 de março de 2013.

${ }^{145} \mathrm{~A}$ citação é de Didier Lahon, O negro no coração do Império. Uma memória a resgatar - séculos XV-XIX, Lisboa, Colecção Entreculturas, 1999, p. 59-60.

${ }^{146}$ Roger Bastide, Sociología de la religión, Madrid, Ediciones Jucar, 1986.

${ }^{147}$ Matt D. Childs, "Retaining and recreating African ethnic identities in nineteenth-centuty Cuba: the role of Havana's Cabildos de Nación in forging diasporic cultures", texto apresentado na conferência Africanos nas Américas: reconstruindo vidas num Novo Mundo, 1675-1825, University of the West Indies, Barbados, 14 a 16 de março de 2013.
} 